\title{
Hollænderier i Sønderjylland i 1600- og 1700-årene
}

\section{af Peter Kr. Iversen}

Fra slutningen af 1500-årene blev mejeribrug en central del af driften på mange ladegårde og godser i Slesvig og Holsten. Der blev oprettet såkaldte "hollænderier«, og deres »holstenske« smør blev et berømt og efterspurgt kvalitetsprodukt. Fhv. landsarkivar Peter Kr. Iversen har samlet en mængde oplysninger om hollænderiernes historie og om arbejdet $\mathrm{i}$ de store besætninger.

\section{Hollænderiernes opståen og beliggenhed}

I Sønderjylland er der adskillige, der bærer familienavnet Hollænder, især forekommer det på Als. Navnet er egentlig en erhvervsbetegnelse på linie med Smed, Møller, Bager, Kromand og andre. En hollænder var nemlig en person, som forpagtede malkekvæget på en ladegård eller et gods for en årlig sum pr. ko, fremstillede smør og ost og havde fortjenesten ved salget heraf. Navnet og erhvervsbetegnelsen kan føres tilbage til, at folk fra Holland, hollændere, i midten af 1500-tallet på grund af religionsforfølgelse måtte flygte fra deres hjemland. En del af disse flygtninge slog sig ned i Ditmarsken og Ejdersted, hvor de indførte det mere intensive mejeribrug, som de kendte hjemmefra. De blev læremestre med hensyn til smør- og ostefremstillingen, og det lykkedes dem i Ejdersted ved fremavl at forbedre kvægracen, således at køerne kunne give op til 15 liter mælk om dagen, en helt usædvanlig stor ydelse i sammenligning med de tre til fire liter, som køer på adelige godser kunne præstere. Fra Ejdersted spredte hollænderne deres virke til de øvrige marskegne, og i sidste halvdel af 1500-tallet træffes de på det tidligere bispegods Svabsted, hvor de forpagtede marskgårde og gjorde dem til mønsterbrug for smør- og osteproduktion. Også på selve den gamle biskoppelige ladegård høstede man gavn af den nye viden om mejeribrug.'

Men hverken på Svabsted eller på det gamle klostergods Mårkær i Angel, hvor der også $\mathrm{i}$ sidste halvdel af 1500-årene var et betydeligt mejeribrug, var besætningen af køer bortforpagtet, og der var altså her ikke tale om egentlige hollænderier. Her havde man stadig lønnede folk til at forestå fremstillingen af smør og ost, og dette har givet os mulighed for at følge produktionen næsten år for år ved hjælp af de bevarede amtsregnskaber, mens det for de regulære hollænderiers vedkommende kun er muligt at se den samlede 
forpagtningsafgift af koholdet. Egentlige hollænderiregnskaber ses ikke at være bevaret. For Svabsteds og Mårkærs vedkommende kan der dog næppe være tvivl om, at mejeribruget dér er blevet drevet under påvirkning fra de indvandrede hollænderes viden og kunnen. Det forhold, at der er tale om tidligere henholdsvis bispe- og klostergods kan med henblik på den mere rationelle mejeridrift også have spillet ind, idet man på gejstligt gods på dette område synes at have været længere fremme end på adels- og krongodset. ${ }^{2}$

Også på de gottorpske og på hertug Hans den Yngres ladegårde skete dog tidligt en udvikling inden for mejeribruget, hvilket kan sættes i forbindelse med udvidelsen af ladegårdenes arealer i slutningen af 1500-tallet ved inddragelse af bøndergods. Ganske vist var studeopdræt endnu en tid fremherskende på disse ladegårde, men mejeridriften begyndte at vinde frem her. Til en begyndelse blev det dog drevet ved lønnet medhjælp, ikke ved bortforpagtning af besætningerne af malkekvæg, selvom disse omkring 1600 kunne være ganske betydelige. ${ }^{3}$

Det var som regel mejersker eller mælkedejer, som de også kaldes, der havde ansvaret for fremstillingen af mejeriprodukterne. Som medhjælp havde de et større eller mindre antal piger, samt hyrder og drenge. Disse mejerskers arbejde var værdsat, og deres løn var derfor også ganske betydelig. På den gottorpske ladegård Børm i Hollingsted sogn fik en sådan mejerske således en årlig løn på 10 rigsdaler foruden 6 rigsdaler 16 skilling til beklædning. ${ }^{4}$ Lignende høje lønninger til mejersker træffer man også andetsteds. ${ }^{5}$

En af forudsætningerne for udvidelsen af mejeribruget og indførelsen af hollænderdriften på de hertugelige ladegårde og adelsgodset var indførelsen af kobbelbruget. Ved studeopdrættet havde det ikke været så afgørende, om de marker, der blevet græsset og brugt til høbjærgning, ikke var lige store fra år til år, idet man kunne regulere studeholdets størrelse herefter. Anderledes ved hollænderidrift. Her måtte man have konstante malkekvægbesætninger, og følgelig måtte der være nogenlunde ensartede græsnings- og høbjærgningsmuligheder fra år til år og dermed også lige store kornarealer.

Da udviklingen i sidste halvdel af 1500-årene førte med sig, at mejeribruget gav større fortjeneste end kornproduktion og studeopdrat, indførtes kobbelbruget derfor efterhånden på de hertugelig gottorpske ladegårde og på hertug Hans den Yngres avlsgårde. Og også adelen fulgte trop i Østslesvig. Til en begyndelse blev mejeribruget drevet på hertugernes eller godsejernes regning, men snart blev man indenfor den gottorpske administration klar over, at man fik større økonomisk udbytte ved at bortforpagte malkekvægbesætningerne til whollændere«. Allerede 1605 var besætningen på ladegården Palhorn i Erfde sogn bortforpagtet til to "hollændere« ved navn Malte og Johannes Simersen, men det er ikke helt klart, om de var af hollandsk afstamning. ${ }^{6}$ I Angel træffer man den første hollænder på godset Runtoft eller Rundhof $i$ Eskris sogn så 
tidligt som $1614^{7}$, og 1619 har Laurenz Petersen forpagtet køerne på godset Sehested i sognet af samme navn i Dänischwohld. ${ }^{8}$ Også på Als har man ret tidligt haft kendskab til et mere avanceret mejeribrug. Før 1650 har der været hollænderi på Gammelgård i Ketting sogn, og på Rumohrsgård i Notmark sogn, måske allerede i Hans den Yngres tid. ${ }^{9}$ Hos sidstnævntes efterkommere på Sundeved og i Angel var malkekvægbesætningerne på de fleste avlsgårde bortforpagtet til hollændere fra midten af 1600-tallet; men det var relativt små besætninger på 30-50 køer, det drejede sig om her, jfr. bilaget side 111f. På Nordals nævnes hollænderier også i sidste halvdel af 1600-årene. På Nordborg ladegård er der en Poul Hollænder $1681^{10}$, og på Mjelsgård i Oksbøl sogn er der et regulært hollænderi 1692. På Østerholm i Egen sogn og Hjortspring i Svenstrup sogn træffer man hollænderier 1696, men de har formentlig eksisteret langt tidligere. På Sydals påtræffes hollænderier omkring 1700. Det gælder Sønderborg ladegård, Nygård og Hjortholm på Kegnæs, Kegnæsgård i Lysabild sogn, Rønhave i Ulkebøl sogn og Majbølgård i Hørup sogn. På de ærøske ladegårde, der en tid lang hørte under Lyksborg, var hollænderidriften i hvert fald indført i de første årtier af 1700-tallet, men vel også her tidligere.

På det nordslesvigske fastland uden for det lyksborgske område på Sundeved og det adelige Gram gods, hvor der ca. 1684 træffes en hollænder Lars Andersen, synes man at have været noget senere på færde. På de søgårdgråstenske gårde træffes hollænderi på Kelstrup i 1710, på Årup i 1717, på Søgård i 1720 og på Kiding i 1720. På Avnbølgård og Fiskebæk ses de først næunt 1734, men også her gælder det, at de godt kan have eksisteret tidligere.

I Haderslev amt var udviklingen anderledes. Her fik hollænderne ikke rigtig fodfæste. Ganske vist synes der i 1600-årene at have været nogen hollænderidrift, idet der i en beskrivelse 1707/08 af Haderslev ladegård tales både om et lille hollænder- og et gammelt hollænderihus. Også på ladegårdene Refsø og Tyrstrupgård omtales hollænderibygninger, men ikke på de øvrige ladegårde. ${ }^{11}$ Om hollænderierne i Haderslev amt kan føres tilbage til Hans den Ældres oprettelse af nye ladegårde og udvidelse af andre får stå hen. Mejeridriften er dog blevet opgivet ret hurtigt på de haderslevske ladegårde, og på kvægsygens tid 1745-46 blev der på dem i hovedsagen opfedet stude. Ud over de lyksborgske godser var der i Angel som nævnt hollænderier på Runtoft og dette gods' underliggende avlsgårde, men også på Satrupholm blev der i sidste halvdel af 1600-tallet oprettet hollænderier, som var af anselig størrelse, og hvis samlede kobesæatning i tiden 1661-1726 voksede fra 290 til 570 køer.

I Svans træffer man hollænderier i sidste halvdel af 1600-årene, på Gereby i Svans sogn således 1657 og på Eskildsmark i Kosel sogn 1686, og i første halvdel af 1700-tallet findes de overalt på halvøens store, adelige godser, og det samme er tilfældet i Dänischwohld; jfr. bilaget side $111 \mathrm{f}$. 


\section{Hollænderikontrakter}

En væsentlig kilde til viden om driften af hollænderierne er de kontrakter, der blev oprettet mellem ejer eller som regel dennes pensionær, d.v.s forpagter af avlsgårdene og hollænderen. Det fremgår af disse kontrakter, at en ladegårds eller adelig avlsgårds malkekvægsbesætning som regel på årsbasis blev bortforpagtet af pensionæren til en hollænder for en årlig afgift pr. ko. Da kontrakten var afsluttet mellem pensionær og hollænder, træffer man kun sjældent disse kontrakter $i$ de kongelige og hertugelige arkiver $-i$ almindelighed amtsarkiverne - eller i de adelige godsarkiver. Af de få bevarede kontrakter vil derfor indholdet af to $\mathrm{i}$ det store og hele enslydende fra de kongelige ladegårde Østerholm i Egen sogn og Hjortspring i Svenstrup sogn blive refereret. De blev 1725 afsluttet mellem pensionær på Østerholm Peter Jacobsen og hollænder Jørgen Lassen og mellem de to pensionærer på Hjortspring, samme Peter Jacobsen og Peter Matzen, på den ene side og hollænderinden Margrethe Christens på den anden. ${ }^{12}$

Kontrakterne går fra maj 1725 til maj 1726, og de omfatter for Østerholms vedkommende $120 \mathrm{k} ø e r$ og tre tyre og for Hjortsprings 122 køer og fire tyre. I kontrakterne er fastsat, hvilke marker eller kobler køerne må græsse på, både dem der må græsses på hele sommeren og dem, der må afgræsses, når hø og korn er høstet. På disse marker fik hollænderne ret til at græsse seks køer, som de selv ejede, samt to heste og 12 får. Sammen med hollænderkøerne havde den østerholmske pensionær dog lov til at græsse 10-12 heste eller kreaturer og den hjortspringske fire hopper. Fremmede kreaturer måtte hollænderne derimod ikke lade græsse blandt køerne.

Når køerne var på stald, skulle hollænderne have tildelt det nødvendige foder i form af hø og halm, som de skulle fodre med »i beskedenhed «, og de og deres medhjælpere måtte ikke tilegne sig mere foder, end der blev tildelt dem af pensionærerne, heriblandt også på begge ladegårde en ugentlig tildeling af nogle sække havre til de private heste.

De to hollændere skulle sørge for, at deres piger ikke førte unødig kiv med andre på gårdene, og i særdeleshed skulle de give agt på, at folkene i de store stråtækte bindingsværksbygninger omgikkes forsvarligt med ild og lys. De skulle selv være til stede, når der blev fodret eller udført andet arbejde $\mathrm{i}$ staldene. Hvis nogle af køerne kreperede i forpagtningsperioden, skulle pensionærerne i løbet af 14 dage indsætte andre køer, således at der på de to ladegårde stadig var fulde besætninger. Dette var en bestemmelse, som senere efter 1745 skulle vise sig at få stor betydning for langt de fleste ladegårdes hollænderier.

Det, som imidlertid var vigtigst for de to hollænderes økonomi, var afgiften af køerne, som for begge gårdes vedkommende var sat til seks rigsdaler pr. 
ko, altså henholdsvis 720 og 732 rigsdaler, og betalingen skulle falde $i$ to terminer - til Mortensdag med henholdsvis 620 rigsdaler og 610 rigsdaler og til majdag med 100 og 122 rigsdaler. Denne form for betaling kunne andetsteds være ordnet på en anden måde.

Uden betydning for hollænderne på de to ladegårde var det ikke, at de kunne rekvirere hovbønderne til at køre produkterne til vandet, og vigtig for økonomien var bestemmelsen om, at de toldfrit kunne ind- og udføre deres produkter og varer.

\section{Forpagtningstidens længde}

Hollænderikontrakterne indeholdt $\mathrm{i}$ almindelighed de samme bestemmelser som dem, vi har mødt $i$ de nordalsiske fra 1725 , men der kunne dog være afvigelser. Til tider har der været afholdt licitation over hollænderierne, således at den højstbydende fik overladt kobesætningen. Dette var bl.a. tilfældet på Østerholm 1702, da Rasmus Rasmussen fra Holbæk fik tilslag for 5 rigsdaler 44 skilling pr. ko. ${ }^{13}$

Kontrakterne blev som regel indgået for et år ad gangen, men de kunne fornyes, således at samme mand eller kvinde kunne have forpagtning to eller flere år i træk. Claus og Paul Rabe Hollænder nævnes således på Nordborg ladegård i 1680'erne og 1690'erne. ${ }^{14}$ Boy Hansen var hollænder på Østerholm 1728-30, Margrethe Christens og Hans Clausen på Hjortspring henholdsvis 1725-27 og 1727-32.

På de lyksborgske godser i Sundeved og i Angel løb kontrakterne i almindelighed over en længere årrække. Lewe Jacobsen træffes således som hollænder på Lundsgård i Ullerup sogn 1668-84, og han efterfølges af Claus Boy, der havde hollænderiet $i$ hvert fald indtil 1700, da hovmester Engel Christoff von Reventlow overtog avlsgården i forpagtning sammen med Philipsborg i samme sogn. Her nævnes Jørgen Foged 1700 som hollænder, men han kan godt have haft forpagtningen tidligere, lige så vel som Claus Boy kan han have fortsat under den nye pensionær.

Efter navnene at dømme synes Peter Petersen 1674 at have overtaget kobesætningen på Nygård på Broager efter faderen Peter Nissen, og han havde hollænderiet indtil 1696, da det blev overtaget af Asmus Dues. I øvrigt er det værd at bemærke, at såvel på Sophienhof i Kværn sogn, Krammark på Broager og Philipsborg havde de lokale hertugelige fogder i mange år hollænderierne i forpagtning. Om disse så har drevet dem for egen regning ved hjælp af en mejerske, eller om de har videreforpagtet køerne til en hollænder, melder kildematerialet intet om. 
På Krammark sker 1689 den ændring, at hollænderiet overtages af Peter Kornbeck, og på Skellegård var besætningen i slutningen af 1600-tallet bortforpagtet til de hidtidige hollændere, henholdsvis Asmus Dues, herredsfoged Johan Jessen og Peter Kornbeck, og de har sandsynligvis drevet mejeribruget som hidtil..$^{15}$ Ligesom i de lyksborgske distrikter på Sundeved og i Angel har man også andetsteds i Angel, i Svans og Dänischwohld haft flerårige hollænderikontrakter, men det normale har været étårige. Hollænderne var et lidet bofast folkefærd. ${ }^{16}$

\section{Hollænderne}

Det var som navnet siger oprindeligt indvandrere fra Holland, der overtog mejeridriften og forpagtningen af malkekvægbesætningerne på de slesvigske ladegårde og godser. Mange hollandske navne synes imidlertid ikke overleveret i det slesvigske, som tilfældet skal være det i Holsten. ${ }^{17}$ På den gottorpske ladegård Palhorn i Erfde sogn blev hollænderiet 1605 forpagtet af de to brødre Malte og Johann Simesen, og her er der nok tale om to mænd, der enten må være indvandret fra Holland eller som nedstammede fra en indvandrer. ${ }^{18}$ På Opdrup i Satrup sogn træffes 1669 en hollænder Owen Mummen, og på Bondsbøl i Havetoft sogn, ligeledes mejerigård under Satrupholm, er der på samme tid en hollænder Boy Owens, som efter navnene at dømme kan være af hollandsk afstamning. ${ }^{19}$ Og det samme kan være tilfældet med Marx Obransen, der 1705 navnes som hollænder på Gereby i Svans sogn. ${ }^{20}$ På Hemmelmark og Mohrberg i Svans kan navne som Jacob Jansen, Berend Willumsen, $\mathrm{H}$. Betting og Hans Hinrich Dugge antyde hollandsk afstamning, men på de alsiske, sundevedske og angelske godser og ladegårde må hollænderne efter navnene at dømme være af sønderjysk herkomst. Det galder i hvert fald Jørgen Jebsen, der var født i Blans, Ullerup sogn ca. 1617 som søn af gårdmand Jacob Jebsen, og som senere blev hollænder på Høgebjerg i Løjt sogn. ${ }^{21}$ Om Rasmus Rasmussen, der 1702 overtog den østerholmske hollænderibesætning vides, at han kom fra Holbæk. ${ }^{22}$ Et enkelt fremmed navn kan dog nævnes fra det nordslesvigske - Rabe. Det forekommer to gange, nemlig på Nordborg ladegård, hvor Paul Rabe var hollænder i 1680'erne og 1690'erne. Han kan være identisk med den hollænder af samme navn, der døde i Lyksborg den 28. juli 1719. På Skeldegård havde Adrian Rabe, vel en slægtning til Paul Rabe, hollænderiet, samtidig med at han var herredsfoged i Nybøl herred. ${ }^{23}$

På visse alsiske hollænderier var der både $i$ slutningen af 1600-årene til henimod midten af 1700-årene mejersker eller mælkedejer, som forestod mæl- 
kens behandling. Det var således tilfældet på Gammelgård, hvor en mandlig hollænder først ses næunt $1667,{ }^{24}$ og på Nordborg til omkring $1670 .{ }^{25}$ På Hjortspring nævnes en kvindelig hollænder 1700 , og det var også tilfældet 1725-26, da Margrethe Christens havde forpagtningen. ${ }^{26}$

På Rønhave var der en mejerske $1726^{27}$ og 1752 ligeledes på Sønderborg ladegård ${ }^{28}$ På Gram blev mælkens behandling som andetsteds omtalt ca. 1750 forestået af mejersken Armgard Jochumsdatter, men hun var på fast løn, 10 rigsdaler årligt, og måtte aflægge regnskab overfor sit herskab. ${ }^{29}$

\section{Afgiften af hollænderikøerne}

Fra sidste halvdel af 1600-tallet haves der fra det lyksborgske område på Sundeved og i Angel gode oplysninger om hollændernes forpagtningsafgifter. Der skete $i$ denne periode et endog ganske betydeligt fald $i$ den årlige afgift pr. ko, og det er ganske interessant at bemærke, at der mellem nærliggende hollænderier kunne være forskelle. På Nybøl i Kværn sogn betaltes 16667 rigsdaler pr. ko, mens hollænderen på Lundsgård i Ullerup sogn kunne nøjes med at betale 6 rigsdaler 2 mark. Fra 1672-74 betaltes der på alle lyksborgske hollænderier 7 rigsdaler pr. ko, men derefter faldt afgifterne, og de bliver igen forskellige. På Nygård på Broager og Lundsgård betaltes $167761 / 2$ rigsdaler, mens afgifterne på Krammark og Philipsborg i Ullerup sogn var nede på 6 rigsdaler både 1677 og 1678. De sænkes yderligere 1688 og århundredet ud på Sundeved og Broager til 5 rigsdaler 1 mark, mens de på Sophiegård, det senere Frederiksdal, og på Nybøl, begge i Kværn sogn holdt sig på 6 rigsdaler. ${ }^{30}$ På Gram gods har man 1684 oplysning om en årlig afgift på 5-6 rigsdaler pr. ko. ${ }^{31}$

Efter 1700 flyder oplysningerne om forpagtningsafgifterne noget rigeligere. Ved århundredeskiftet var afgiften på de relativt store malkekvægbesætninger på Østerholm, Hjortspring og Nordborg henholdsvis 5 rigsdaler 44 sk., 5 rigsdaler og 5 rigsdaler 16 skilling. Da disse ladegårde i 1720'erne kom under kongelig administration, blev afgiften forhøjet til 6 rigsdaler courant for dog i 1729 og 1730 at blive reduceret til henholdsvis 5 rigsdaler 40 skilling, 5 rigsdaler 24 skilling og 5 rigsdaler 32 skilling. ${ }^{32}$

Ikke uventet ligger afgifterne på de sydalsiske ladegårde på lignende niveau. På Hjortholm og Nygård på Kegnæs var afgiften 17205 rigsdaler 36 skilling og på Hjortholm og Nygård på Kegnæs var afgiften 17205 rigsdaler 36 skilling og på Hjortholm 17325 rigsdaler 16 skilling pr. ko. ${ }^{33}$

På de søgårdske godser var afgifterne noget højere. På Kelstrup således 17206 rigsdaler 23 skilling, på Årup 17256 rigsdaler 35 1/2 skilling, 17316 
rigsdaler 26 skilling og på Kiding hele perioden 1728-45 7 rigsdaler 21 1/2 skilling. ${ }^{34}$

På Runtoft og Drølt i Angel var den årlige afgift 17067 rigsdaler og 1725 7 rigsdaler 24 skilling. På Udmark i Eskris sogn betaltes 17137 rigsdaler. ${ }^{35}$

Fra Svans foreligger der oplysninger fra Hemmelmark, hvor afgiften 1711 var $61 / 2$ rigsdaler og 17366 rigsdaler, Mohrberg, hvor afgiften før 1745 varierede mellem 5 rigsdaler 32 skilling og 6 rigsdaler 40 skilling, samt Gereby, hvor der 1738 måtte betales 7 rigsdaler 24 skilling pr. ko. ${ }^{36}$

I de nærmeste år efter kvægsygen 1745 (se herom senere) skete der en voldsom stigning $\mathrm{i}$ afgiften. Hele besætninger var blevet udryddet, og den store efterspørgsel efter malkekøer medførte naturligvis ikke blot, at de steg i pris, men at også hollændernes afgifter steg tilsvarende, måske endda mere. På Hemmelmark og Mohrberg var afgifterne således 17479 1/2 rigsdaler og 1748 10 rigsdaler pr. ko. På disse to godser var indkøbsprisen for en hollænderko før 1745 7-10 rdl., men steg lige efter 1745 til op imod 15 rdl. ${ }^{37}$ På Runtoft og Drølt i Angel var forpagtningsafgiften pr. ko 174612 rigsdaler og 175010 $1 / 2$ rigsdaler. ${ }^{38}$ Efterhånden som besætningerne igen blev mere eller mindre fuldtallige, faldt såvel pris som afgift til et mere naturligt leje, for dog at stige efter en ny epizooti i begyndelsen af 1760 'erne. På Søgård var den gennemsnitlige afgift 17648 rigsdaler 2 skilling. ${ }^{39}$

Blandt årsagerne til de varierende forpagtningsafgifter kan nævnes fodringsog græsningsforholdene. Hvor disse var gode, kunne køerne give mere mælk, og følgelig kunne afgiften sættes i vejret. Også beliggenheden i nærheden af en større by med mulighed for mælkesalg og direkte afsætning af smør og ost til borgerne havde indflydelse på afgiften. ${ }^{40}$

Forskellen $\mathrm{i}$ forpagtningsafgiften kunne således være ganske betydelig og kunne før kvægpesten 1745-46 svinge fra 5 rigsdaler til $71 / 2$ rigsdaler alt efter tid og sted, og heroverfor står den slesvig-holstenske landøkonom J.B.Dantzmanns oplysning fra midten af $1750^{\prime}$ erne om en middelpris på 6 7 rigsdaler. $^{41}$

I de tidligere refererede kontrakter fra Østerholm og Hjortspring på Nordals fra 1725 er forpagtningsafgiften fastsat til betaling $i$ to terminer, nemlig således at der for sommerperioden fra majdag til Mortensdag betaltes 5 rigsdaler 8 skilling pr. ko og fra Mortensdag til majdag 40 skilling, altså i alt 6 rigsdaler pr. ko på årsbasis. På Hjortholm på Kegnæs havde man en lignende ordning, dog at sommerafgiften her var forholdsvis mindre end på de nordalsiske ladegårde, nemlig 4 rigsdaler 16 skilling af en samlet afgift på 5 rigsdaler 16 skilling. ${ }^{42}$ På Eskildsmark i Svans skulle betalingen falde i tre terminer, nemlig til majdag, Bartholomæi og Mortensdag. På Hemmelmark kunne der endda være fire terminer. ${ }^{43}$ 
Titelblad af den slesvigholstenske landokonom Johann Balthasar Dantzmanns vejledning for driften of et hollanderi. Skriftet, der findes på Schleswig-Holsteinisches Landeshibliothek $i$ Kiel, er indbundet sammen med et par andre landokonomiske skrifter og har $i$ Grasten haft forskellige ejere, forst "Madamer Tychsen, senere F. Thomsen.

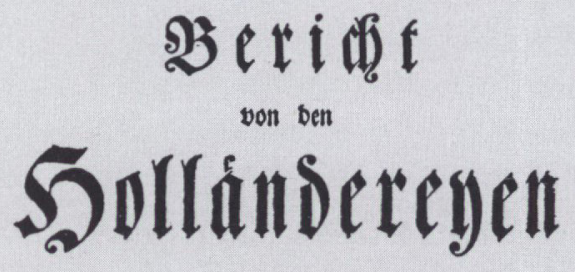

in Den

Setrogthüutetn

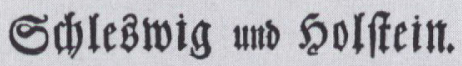

"

Stlúcfítadt,

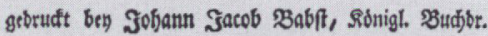

1755 .

I almindelighed er der i hoverikontrakterne angivet en enhedspris for samtlige køer i hollænderibesætningerne uanset køernes alder, men der kunne aldersmæssigt naturligvis være forskelle i køernes ydelse, og derfor ser man dem også nogle steder opdelt $i$ aldersklasser med forskellige afgifter. På den nordalsiske ladegård Mjelsgård, hvor der 1704 var 80 hollænderikøer, blev disse $\mathrm{i}$ kontrakten opdelt $\mathrm{i}$ fire klasser, nemlig

\begin{tabular}{lcl} 
Antal køer: & Alder: & Afgift pr. ko: \\
\hline 20 & $6-7$ år & 7 rigsdaler \\
20 & $8-10$ år & 6 rigsdaler \\
20 & $11-13$ år & 5 rigsdaler \\
20 & $14-17$ år & 4 rigsdaler
\end{tabular}

Gennemsnit pr. ko altsả 5 1/2 rigsdaler

Endnu mere specificeret var alder og afgift i en kontrakt samme sted fra 1731. Antallet af køer var stadig 80 , men nu så billedet således ud: 


\begin{tabular}{lcl} 
Antal køer: & Alder: & Afgift pr. ko: \\
\hline 27 & $6-7$ år & 6 rigsdaler \\
20 & $8-10$ år & 5 rigsdaler \\
11 & $11-13$ år & 5 rigsdaler 32 skilling \\
17 & $14-15$ ar & 4 rigsdaler 16 skilling \\
3 & $15-17$ år & 3 rigsdaler 16 skilling \\
2 & 17 år & 2 rigsdaler
\end{tabular}

I gennemsnit bliver afgiften her 5 rigsdaler 29 skilling. Det man især bemærker er, at afgiften for de $11-13$ årige køer er højere end for de $8-10$ årige. $^{44}$

Lidt andre afgiftsmodeller var der på Kelstrup, på Årup og på Kiding, hvor den gennemsnitlige årlige forpagtningsafgift var henholdsvis 6 rigsdaler 23 skilling, 6 rigsdaler $351 / 2$ skilling og 7 rigsdaler $211 / 2$ skilling. ${ }^{45}$

Man får af forpagtningsafgifterne et ganske tydeligt indtryk af, at køerne under 10 år var så absolut de mest værdifulde, og man kan stille sig noget spørgende overfor, om der virkelig har kunnet være økonomi $i$ at holde de relativt mange gamle køer, uanset at der kun blev givet en beskeden afgift af dem. Vinterfoder og græsning kom jo stort set ud på et, hvad enten koen var ung eller gammel.

På Gram havde man 1772 en helt anden form for aftale med hollænderen. Han fik 50 køer stillet til rådighed af herskabet, men kunne derudover selv indsætte så mange køer, som der var græsning og foder til. Ligeledes kunne han holde så mange svin, som han ville, dog måtte de ikke forvolde skade. I tilfælde af oldenår måtte han holde 20 svin frit $\mathrm{i}$ skoven, og de hovpligtige undersåtter skulle køre hollænderprodukter indtil fire mil. Forpagtningsafgiften var 1600 rigsdaler. ${ }^{46}$

Mellem afgiften af hollænderikøerne og smørprisen kan der anes en vis sammenhæng. Således faldt afgiften på de lyksborgske ladegårde i slutningen af 1600-tallet fra 6 rigsdaler til 5 rigsdaler 1 mark pr. ko samtidig med, at smørprisen faldt fra 20 rigsdaler pr. tønde til $171 / 2$ rigsdaler, ja for vintersmørrets vedkommende til 14 rigsdaler ${ }^{47} \mathrm{Og}$ i sidste halvdel af 1720 'erne faldt afgiften af køerne på de nordalsiske ladegårde fra 6 rigsdaler til 5 rigsdaler 32 skilling samtidig med, at markedsprisen i Rendsborg pr. tønde smør faldt fra 20 rigsdaler 30 skilling til 18 rigsdaler 26 skilling. ${ }^{48}$

Nogen større sammenhæng mellem afgiften af køerne og hollænderiernes størrelse ${ }^{49}$ synes der ikke at have været, selv om der måske kan skimtes en vis rationaliseringsgevinst ved de større brug. Her har hollænderiernes beliggenhed og fodringsmuligheder nok spillet en større rolle på den måde, at når smørprisen var lav og hollænderiafgiften som følge deraf fulgte trit nedad, var godsherskab eller pensionær tilbøjelig til at sætte flere køer ind, så at samme økono- 
miske udbytte kunne opnås. Man har så udpint marker og enge mest muligt, men med det resultat, at mælkeydelsen pr. ko blev formindsket til skade for hollænderen. I sit skrift tilråder Dantzmann ${ }^{50}$ da også, at der ikke må holdes flere køer, end der er græsning og vinterfoder til. Hellere for få køer end for mange, da man derved fik mere mælk og stort set samme gødningsmængde. I øvrigt regnede man med, at forpagtningsafgiften af hollænderikøerne som regel udgjorde halvdelen af et gods' eller en ladegårds indtægter.

\section{Besætningernes størrelse og sammensætning}

Som det fremgår af bilaget var der ganske betydelige forskelle i hollænderiernes størrelse - både topografisk og tidsmæssigt. De lyksborgske i Sundeved og Angel var små og voksede kun lidt $i$ de årtier af 1600-tallet, hvorfra der haves oplysninger. Med undtagelse af Nybøl i Kværn sogn, hvor bestanden af malkekvæg steg fra 76 i 1666 til 100 i 1693, var der kun besætninger på mellem 40 og 60 køer.

På de alsiske ladegårde var koholdet større, og det voksede fra gennemsnitlig 100 omkring 1700 til ca. 150 ved kvægsygens udbrud 1745. Størst var besætningerne på Sønderborg ladegård og Nygård på Kegnæs, hvor der begge steder 1720-30 var 170 køer. Rønhave og Majbølgård havde kun små kohold på ca. 60. De ærøske hollænderier på Søbygård og Marstal havde 1720 henholdsvis 120 og 110 køer.

Udover de lyksborgske hollænderier i Sundeved var der kun få på det nordslesvigske fastland. Gram havde 1740264 og 1760249 stk. malkekvæg, og på de søgård-gråstenske godser var der også nogle større hollænderier, som på kvægsygens tid talte 160-180 køer; endvidere var der et par mindre på 3060 køer.

Når der ses bort fra de lyksborgske, havde hollænderierne i Angel i første halvdel af 1700-årene en ganske anselig størrelse - helt op til 300 køer på Østergård og Runtoft, men mere normalt var der 100-145 køer. I Svans fandtes også store hollænderier, men de største som Ludwigsburg i Vabs sogn og Saxtorf i Risby sogn med $400 \mathrm{køer}$ var dog delt op i mindre enheder, hvilket også var tilfældet på Runtoft.

I almindelighed hørte køerne til lade- og hovedgårdenes faste inventar, som overtoges af forpagterne, pensionærerne, sammen med det øvrige inventar, og derfor kaldtes disse køer inventariekøer. Men derudover kunne pensionærerne selv eje en del køer, som ligeledes bortforpagtedes til hollænderne. Disse kunne ydermere selv eje nogle køer, og for at man kunne kende forskel på de forskellige kategorier, blev køerne brændemærket eller snittet $i$ ørerne. ${ }^{51}$ 
På de alsiske ladegårde var der i 1. halvdel af 1700'årene mange treårige køer, men der var også ganske mange, der var over 14 år. På Nordborg ladegård, der 1707 havde en hollænderibesætning på 110, var der således 54 3-8 års køer, 36 8-12 års og 20 12-16 års. Det ser dog ud til, at man omkring 1730 har opgivet treårskælverne, for $\mathrm{i}$ hvert fald findes ingen i den aldersklasse på Mjelsgård og Østerholm, men til gengald findes to 17-årige på Mjelsgård og tre 17-19-årige på Østerholm. ${ }^{52}$ Endnu så sent som 1805 havde man på Gammelgård i den store malkekvægbesætning på 1807 køer, der var 18 år gamle og 6 på 17 år. I den yngste ende var der 9 2-års og 12 3-års. Her må man dog være blevet ked af de gamle køer, idet der 1811 i en besætning på 178 køer kun var 8 over 13 år, mens man 1805 havde haft 26 over den aldersgrænse. ${ }^{53}$ I aldersmæssig henseende så hollænderiernes besætninger altså helt anderledes ud end tilfældet er med store kobesætninger $i$ dag.

Men også på anden måde skilte de sig ud fra moderne kvæghold. Thi køerne strålede i næsten alle regnbuens farver. På Østerholm var besætningen 1732 sammensat af 47 sorte og 15 sortbrogede, 7 grå og 6 gråbrogede, 1 blå og 5 blåbrogede, 9 røde og 12 rødbrogede samt 2 hvide. På Hjortspring var der 28 røde og 16 rødbrogede, og man synes her $i$ nogen grad at have lagt vægt på at fremavle røde kreaturer, idet tre store, røde marskkøer fremhæves som noget særligt. Man havde også to røde tyrekalve til indsætning i avlen, men kun en grå og en blå. Til farveangivelsen skal dog bemærkes, at blandt de sorte og røde er også de hvidhovede medregnet.

Det mest farveprægtige skue synes malkekvægbesætningen på Sønderborg ladegård at have udgjort. Her nævnes blegrøde, røde, grå, sorte, rødbrogede, sortbrogede, blåbrogede, lysegrå, sortryggede, kulsorte, gråbrogede, helt hvide, blå, brune, sortstjernede og hvide med sorte ører. De grå var i overtal. ${ }^{54} \mathrm{På}$ Søgård bestod besætningen 1747 næsten udelukkende af sorte, sortbrogede, grå og gråbrogede køer. ${ }^{55}$ Alt $\mathrm{i}$ alt må det siges, at de sorte og sortbrogede køer var dominerende i sammenligning med de røde og rødbrogede.

Som nævnt kan det synes, at man på Hjortspring har søgt at forbedre besætningen ved anskaffelse af køer udefra, men der kendes derudover kun få forsøg på forbedringer ved indkøb af fremmede avlsdyr. Mest konsekvent $i$ den henseende synes lensmanden på Møgeltønderhus Albret Skeel at have været. Han havde øjnene åbne for, at der på mejeribrugets område var en god del at lære i Holland og lod 1618 borger i Ribe Laurids Struck indkøbe en tyrekalv og to kviekalve dér. I denne forbindelse udtrykte han håbet om, at disse avlsdyr måtte have gavnlig indflydelse på kobesætningen på Møgeltønderhus. ${ }^{56}$ På Hemmelmark i Svans blev der i midten af 1700 -tallet hvert år indkøbt nye tyre $e^{57}$, men ellers var man meget tilbageholdende med at at tilføre nyt blod udefra. På alsiske hollænderier blev der som regel hvert år tillagt en 


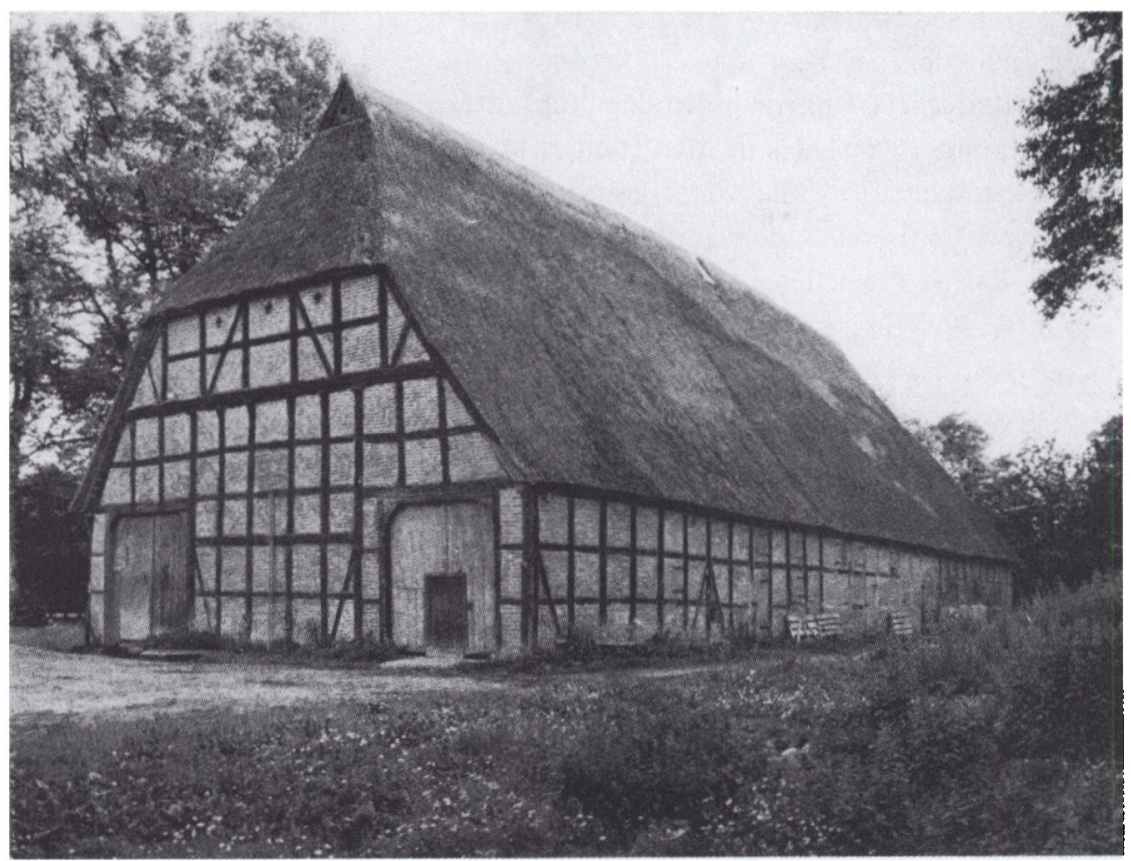

På de store godser $i$ Sydostslesvig og i Holsten er der endnu bevaret flere imponerende bindingsvarkslader som udtryk for tidligere tiders landbrug. Her laden pả herregärden Wulfshagen $i$ Gettorp sogn $i$ Sydslesvig.

halv snes kviekalve for hver 100 køer. ${ }^{58}$ Man var således under normale forhold selvforsynende med tillæg.

Kvægsygen $1745 \mathrm{ff}$ medførte dog, at der måtte tilkøbes mange dyr udefra - ja, der kan vel næsten tales om fuldstændig fornyelse af besætningerne. Alligevel var det langt ind i 1800-tallet god latin, at de slesvigske og holstenske hollænderibesætninger bedst kunne forbedres ved indavl, og kunne det ikke lade sig gøre, skulle man købe køerne i nabolaget. ${ }^{59}$ Med hensyn til tyre, som var holdt uden for hollændernes afgift, regnedes da $\mathrm{i}$ almindelighed med 2 3 tyre til en besætning på 100 køer, og de græssede sammen med køerne. Man måtte derfor sørge for, at de ikke blev gjort vilde som kalve, og at de ikke blev vænnet til at stange. Men stangede de alligevel, måtte de have hornene savet af eller have et bræt bundet for øjnene. Tyrene blev ikke over fem år gamle, og man foretrak helt unge og små tyre, da de store ofte kunne gøre skade på køerne. ${ }^{60}$ Hollænderiernes tyre stod som regel til fri afbenyttelse for pensionærerne og eventuelle fogeders private køer, samt i visse tilfælde også for kådnernes køer. ${ }^{61}$ 


\section{Køernes ydelse}

Så vidt vides, har ingen hollænder efterladt sig regnskaber; jfr. dog s. 105. M.h.t. køernes ydelser kan man imidlertid til en vis grad sammenligne med de besætninger, der ikke var bortforpagtede, men som blev drevet direkte under ladegårds- eller godsadministrationerne. For Sønderjyllands vedkommende kan der således foretages beregninger fra kongelige og hertugelige ladegårde omkring 1600 , beregninger som viser, at der fra egn til egn og fra ladegård til ladegård var ganske store forskelle. Iøjnefaldende er forskellen mellem ydelserne på de kongelige ladegårde i Haderslev og Rendsborg amter sammenlignet med ladegårdene i de gottorpske amter. På de kongelige ladegårde holdt man $\mathrm{i}$ modsætning til de gottorpske fast ved studeopdræt og -fedning og gjorde meget lidt ud af mejeribruget. Man måtte derfor på de kongelige ladegårde omkring 1600 regne med et årligt smørudbytte på omkring en halv snes kg. pr. ko, mens man på den gottorpske, løgumklosterske ladegård kunne regne med en snes kg., og på Brundlund ladegård ved Aabenraa var køernes gennemsnitlige ydelse ca. $30 \mathrm{~kg}$. på årsbasis. På ladegårdene i Tønder og Husum amter, hvor man havde god græsning og rigelige hømængder, nåede man endda op på henholdsvis 45 og $40 \mathrm{~kg}$. Klarest tegner en ko's årsydelse sig dog på Mårkær og Svavsted, hvor man har sammenhængende oplysninger over lange perioder, for Mårkærs vedkommende således fra 44 årsregnskaber i tiden 1579-1631 og for Svavsteds vedkommende 15 regnskaber i tiden 157278. For Mårkærs vedkommende kan man fra denne tid regne med et årsgennemsnit på ca. $30 \mathrm{~kg}$. pr. ko, mens man på Svavsted når op på $40 \mathrm{~kg}$. Man lagger her mærke til den ganske betydelige forskel mellem ydelserne i Angel og i Vestslesvig med de store givtige engarealer. ${ }^{62}$

Også på det kongerigske Møgeltønderhus har køerne i de første fire årtier af 1600-tallet ydet særdeles godt med over $50 \mathrm{~kg}$. ${ }^{63}$, og på Trøjborg ydede 18 køer 1603 i gennemsnit $43 \mathrm{~kg} .{ }^{64}$ - I nutiden er tallene helt andre. En ko i Sønderjylland yder i dag årligt $285 \mathrm{~kg}$ smør i årsgennemsnit - alene dette viser, hvilken udvikling der har fundet sted i landbruget gennem århundrederne.

Fra 1600-årene foreligger meget sparsomme oplysninger om køernes ydelse på de adelige godser. Georg Hanssen regner på grundlag af oplysninger fra et enkelt gods med en årsydelse på $25-30 \mathrm{~kg}$. smør. ${ }^{65}$ Fra de lyksborgske ladegårde Philipsborg og Lyksborg har henholdsvis 32 og 23 køer 1668 givet 21,7 og 24,1 kg. smør, men herudover er der solgt for henholdsvis $17 \mathrm{rdlr}$. og 16 rdlr. 32 sk. malk. Også en del surmalk er blevet solgt. På Nygård og Skeldegård med henholdsvis 40 og 24 køer lå smørudbyttet omkring $22 \mathrm{~kg}$. pr. ko. ${ }^{66}$ Ydelserne her har altså ligget en kende under, hvad Georg Hanssen regner med. 
Hedemann-Heespen anslår ca. 1750 en kos daglige mælkeydelse til tre liter eller 1286 liter på årsbasis. Når der regnes med, at der kan fremstilles et $\mathrm{kg}$. smør af 30 liter mælk, skulle der altså på den tid af hver hollænderko kunne fås $45 \mathrm{~kg}$. smør. En noget mindre ydelse når Dantzmann frem til, idet han oplyser, at tre gode hollænderkøer årligt kan give en tønde smør, hvilket svarer til ca. $37 \mathrm{~kg}$. pr. ko, men herudover kan der dog i den bedste tid af mælken fra 200 køer fremstilles $4-5$ oste à $9 \mathrm{~kg}$. daglig. ${ }^{67}$

Disse tal er i nogen grad skønnede, men dog ikke helt ved siden af. De kan stort set underbygges ved oplysninger fra et meget udførligt mejeriregnskab fra Gramgård 1747/48. ${ }^{68}$ Her var der efter kvægsygen et relativt lille kohold, og måske har køerne heller ikke været af de allerbedste. Kobesætningen her øgedes efter kvægpesten fra majdag 1747 til majdag 1748 successivt fra 47 til 72 køer. I mejerske Armgårds ugentlige regnskab over smør- og osteproduktion er antallet af køer anført, og man får derfor mulighed for at udregne ikke blot det gennemsnitlige årsudbytte pr. ko, men tillige kan man få et indtryk af, hvornår på året udbyttet var størst. Det gennemsnitlige udbytte pr. ko var $1747 / 4843,29 \mathrm{~kg}$, altså et tal, der ligger mellem Dantzmans og HedemannHeespens oplysninger. I maj måned gav hver ko gennemsnitlig $1,1 \mathrm{~kg}$. smør om ugen, i juni steg udbyttet til $1,41 \mathrm{~kg}$ og derefter faldt det til $1,3 \mathrm{~kg}$ i juli og august og yderligere til knap $1 \mathrm{~kg}$ i første halvdel af september. Fra sidste halvdel af september til udgangen af oktober lå den enkelte kos ydelse på 0,63 $\mathrm{kg}$ smør, og den nåede et lavpunkt i november med $0,29 \mathrm{~kg}$. Derefter begyndte ydelsen igen at stige. I december når man op på $0,35 \mathrm{~kg}, \mathrm{og}$ omkring årsskiftet er man oppe på $0,38 \mathrm{~kg}$ ugentlig. Allerede i marts er man nået op på $0,95 \mathrm{~kg}$, og på denne ydelse holder besætningen sig til majdag 1748. Disse tal viser, at vinterfodringen på Gramgård ikke har været helt ringe, og at der må have været en del efterårskælvere, som har været med til at hæve gennemsnittet $\mathrm{i}$ vintermånederne.

Man kan af mejeriregnskaberne for Gramgård endvidere se, hvor meget mælk, der skulle anvendes til fremstillingen af et pund smør. I juli 1747 blev der således regnet med 7 kander mælk til et pund smør, hvilket omregnet til moderne mål bliver 26,6 liter til et $\mathrm{kg} .{ }^{69}$ Den 16. september samme år kunne man nøjes med 24,05 liter til et $\mathrm{kg}$, men den 21 . samme måned nærmede man sig igen 26 liter. Også fra 1750 haves et par tal, der oplyser lidt om mælkens fedtindhold. I februar måned skulle der således $72 / 3$ kande mælk til fremstillingen af 1 pund smør eller 29,1 liter til et $\mathrm{kg}$. I april kunne man nøjes med $71 / 2 \mathrm{kande}$ til et pund eller 28,5 liter til et $\mathrm{kg}$., mens man sidst $\mathrm{i}$ august måtte anvende $81 / 4 \mathrm{kande}$ til et pund eller 31,35 liter til et kg. Noget entydigt billede aftegner disse tal ikke, men peger dog i retning mod, at hen på sommeren har der skullet mere mælk til fremstillingen af et $\mathrm{kg}$ smør end tidligere på året. 
I denne forbindelse kan nævnes, at Dantzmann og Niemann ${ }^{70}$ samstemmende oplyser, at det bedste smør fik man efter høst, når køerne var blevet slået på høstgrøde. Derefter fulgte i kvalitet ifølge Niemann junismørret, der ligesom høstgrøde- eller ævredsmørret kunne gemmes til vinterbrug. Hverken smørret fra maj eller fra den varmeste sommertid var godt, og af vintersmørret, dvs fra de måneder, hvor køerne var på stald, var forårssmørret ifølge Niemann noget bedre end efterårssmørret. I øvrigt var der også forskel på smørrets vægt til de forskellige årstider. En tønde sommersmør var således $3-4 \mathrm{~kg}$ tungere end vintersmør, men endnu tungere var sensommersmørret, hvilket som nævnt skyldes, at køerne da var kommet på høstgrøden. ${ }^{71}$

Foruden smør produceredes der også af Gramgårds køer oste. I tiden fra maj til først i august 1747 drejede det sig om 28 oste på måske 6 eller $9 \mathrm{~kg}$. I oktober blev der yderligere fremstillet seks og i tiden fra marts til maj 1748 45 oste. Langt de fleste oste blev altså fremstillet i forårsmånederne og forsommeren. Disse tal må stadig ses i relation til en besætning, der voksede successivt fra 47 køer ved majdag 1747 til 72 majdag 1748.

\section{Kvægsyge}

I kontrakterne med godsejerne eller pensionærerne var hollænderne til en vis grad sikret mod tab, når køerne døde, idet der så skulle indsættes erstatningskøer. Men navnlig efter at forskellige smitsomme kvægsygdomme havde vist sig i 1720'erne og 30'erne, begyndte godsejerne og pensionærerne at gardere sig imod at skulle erstatte alle døde hollænderikøer, og efter kvægpesten 1745 blev dette forbehold generelt. På Satrupholm skulle hollænderen således 1747 for hver $100 \mathrm{køer}$, der døde, selv indsætte 10 nye årligt ${ }^{72}$, mens han på Hytten Ladegård kunne nøjes med $8 \mathrm{om}$ året. $^{73}$

En af de væsentligste årsager til dødsfald $\mathrm{i}$ hollænderibesætningerne var kælvningen i forårsmånederne. På Hjortspring døde således i tiden fra 17. til 28. april 1726 fire køer $^{74}$, men der var mange andre grunde til dødsfald. Af de sygdomme, som hærgede i de første årtier af 1700 -årene, kan næunes lungepesten, en smitsom sygdom, som især plagede i 1720'erne. ${ }^{75}$

På Østerholm og Hjortspring var hollænderierne 1731 angrebet af blodgang, en epizooti, der dog langtfra var så dødbringende, som den $i$ det følgende omtalte kvægpest. På Østerholm begyndte blodgangen fire uger før Sct. Hans og vedvarede i syv uger. I denne periode blev 34 køer syge, og heraf døde de 16 , men af de overlevende havde hollænderen heller ikke stort udbytte. Det oplyses, at to af køerne hele sommeren havde været under behandling af 
smeden i Egen, Chresten Jensen, men at den ene alligevel var kreperet ${ }^{76}$ Også Hjortsprings køer var 1731 plaget af blodgang. ${ }^{77}$

Hollænderne og mejerskerne synes ikke selv at have haft den store evne eller vilje til at kurere på syge dyr. På Nordborg Ladegård tyede man således 1731 ligesom på Østerholm til fremmed hjælp. Jep Schmidt fra Lavensby og hans medhjælper fik da 40 sk. for åreladning af hollænderikøer, og Peter Schmidt i Oksbøl fik otte sk. for olie og møje for at kurere på en ko, der havde fået en lændeskade. Samme år, 1731, var der også blodgang i besætningen på Nordborg. Der døde to køer, og apotekeren i Sønderborg havde til dem måttet levere seks portioner medicin. Marcus Krahmer måtte endvidere levere teriak og skorpium til en anden syg ko dér. De kreperede dyr måtte man ikke selv begrave. Det var Sønderborg-skarpretterens bestilling. ${ }^{78}$

En egenartet situation opstod på Kegnæs 1720, da der på Nygård døde 78 malkekøer og 13 stk. ungkvæg og på Hjortholm 38 køer og 10 stk. ungkvæg på grund af vandmangel. ${ }^{79}$

Disse spredte sygdomsangreb og dødsfald af andre årsager kunne i økonomisk henseende være alvorlige nok både for konge, godsejer, pensionær og hollænder, men skaderne var dog overskuelige i sammenligning med den epizooti, der begyndte i Vestslesvig sidst på året 1744, og som i løbet af 1745 trods skrappe afspærringsforanstaltninger spredte sig til hele landsdelen. $\mathrm{Og}$ pesten skånede hverken kådnerens enlige ko og gårdmandens besætning på 4 - 5 køer eller de store hollænderier. Hvor kvægpesten fik indpas, kreperede næsten hele besætningen, og de få dyr, der overlevede, var meget svækkede og gav meget lidt malk. ${ }^{80}$

I marts 1745 begyndte pesten for alvor at hærge i Svans, og i løbet af april måned var hele halvøen hærget af den. Fra april hører vi om angreb $i$ Dänischwohld og Angel, og også her udryddes den ene hollænderibesætning efter den anden. På Hytten ladegård begyndte det 1. august 1745, og på Ziegelhof møder vi den i december. ${ }^{81}$

Også på adelsgodset i Nordslesvig begynder den noget senere. På Søgård dukker den op hen på sensommeren $1745^{82}$ og på de alsiske hollænderier $\mathrm{i}$ Nordborg amt i oktober 1745. Til Nygård på Kegnæs når den i januar 1746, og i februar 1746 dør hele besætningen på Gammelgård og Kegnæsgård. ${ }^{83}$

Alle hollænderier uden undtagelse led tab p.gr.a. kvægsygen, og kun ganske få kreaturer overlevede. Som eksempler kan nævnes, at på Hjortholm på Kegnæs døde februar 1746182 køer, mens kun to overlevede, på Kegnæsgård døde alle 81 køer. ${ }^{84}$ På Satrupholm i Angel døde fra december 1745331 køer $^{85}$ og på Hytten ladegård ${ }^{86}$ døde 98 køer og en overlevede. På Ziegelhof døde i løbet af en måneds tid fra december 1745 til januar $174680 \mathrm{k} ø e r$, mens en overlevede ${ }^{87}$. 
Til en begyndelse forsøgte man at hindre pestens udbredelse ved omfattende nedslagtninger, men dette ophørte ved udgangen af april $1745^{88}$. Andre foranstaltninger mod udbredelsen af smitten som afspærring af byer eller indespærringer af vagabonder i Rendsborg fæstning hjalp lige så lidt. ${ }^{89}$

De mange syge dyr og ådsler gav en ulidelig stank, og det må have været et særdeles hårdt og ubehageligt arbejde for de hoveripligtige kådnere og bønder at begrave dem. Navnlig efter at Tyske Kancelli havde givet tilladelse til, at ådslerne måtte flås, så huderne kunne sælges og give en beskeden fortjeneste. Talgen måtte dog ikke udskæres og bruges ${ }^{90}$. Normalt var det ellers skarpretterne, som havde privilegium på at flå og begrave ådsler, men de kunne umuligt overkomme dette arbejde i kvægpestens tid.

Næppe var køerne døde, før godsejerne eller pensionærerne begyndte at anskaffe nye dyr, thi nok var det økonomiske tab i sig selv stort, fordi man måtte undvære hollændernes forpagtningsafgift, men det ville blive endnu større, såfremt besætningerne ikke blev retableret, og man som følge heraf måtte savne gødningen til kornmarkerne ${ }^{91}$. Over hele landsdelen var kreaturerne imidlertid døde, og det holdt meget hårdt at få indkøbt erstatningskøer.

Priserne fordobledes derfor også i tiden lige efter 1745. Mens prisen før kvægsygen havde været 7 - 10 rigsdaler pr. ko, var den $i$ fri handel umiddelbart efter 15 rdlr., men det var dog de færreste erstatningskøer, der til den pris kom til at fylde op i hollænderistaldene. Til retablering af besætningerne på de kongelige ladegårde på Als blev der således udstedt ordre om, at de underliggende fæstebønder hver skulle aflevere en af de bedste køer eller den bedste, der havde overlevet kvægpesten, og at de $\mathrm{i}$ erstatning herfor skulle have 10 rigsdaler pr. ko $^{92}$ Det var jo en særdeles ubehagelig fremgangsmåde overfor bønderne, som selv havde lidt katastrofale tab. De kongelige pensionærer fik eftergivet en del af deres forpagtningsafgifter alt efter, hvor stort tab man havde lidt, mens bønderne blev skrevet $\mathrm{i}$ restance for manglende afgiftsbetaling. Også forpagterne på de adelige hovedgårde måtte naturligvis have eftergivelse i deres afgifter, således som det var tilfældet på Søgård 1748 og $1749^{93}$.

For hollænderne gjaldt, at de indtil kvægpesten kun skulle betale af det reelle antal køer, som de havde til malkning. Men dette hørte helt eller delvis op efter 1745. Det kunne derfor heller ikke undgås, at de kom til at lide ganske betydelige driftstab. Dels havde de ikke fortjenesten ved salget af produkterne, og dels skulle malke- og mejeripigerne have kost og løn.

Det var svært at få nye køer, og hollænderne har ikke altid været tilfredse med dem, de fik overladt. De har hist og her haft mulighed for at udskyde nogle som for ringe, og dette smitter igen af på de kongelige pensionærers forpagtningsaftaler med rentekammeret. Forpagterne på de fire nordalsiske gårde Nordborg, Østerholm, Hjortspring og Mjelsgård stillede således 1747 
deres ganske bestemte krav ved leveringen af erstatningskøerne. Til Nordborg og Mjelsgård ønskedes køerne leveret 14 dage før 1. maj 1748, men de skulle være købt før fastelavn, da man ellers ikke havde mulighed for at vurdere dem. Og det ville være det bedste for hollænderierne, at der blev indkøbt unge køer, som havde kælvet to eller tre gange, men førstegangskælvere kunne dog accepteres. For pensionæren på Hjortspring var det dog ikke afgørende, hvornår køerne blev leveret, hvis blot han fik gode, sunde køer. Han så i øvrigt helst, at køerne blev anskaffet lidt efter lidt, og det var efter hans opfattelse hasard at sammenkøbe den nye besætning fra mange forskellige lokaliteter. Han og pensionæren på Mjelsgård ville i øvrigt helst overtage forpagtningen uden hollænderikøer og selv sørge for opdræt, hvorved man efterhånden kunne få besætningen i komplet stand ${ }^{94}$. Mange steder lykkedes det overhovedet ikke at få hollænderibesætningerne op på fuld højde igen. Især var det naturligvis galt, hvor kvægpesten efter et par års forløb igen gik til angreb. Det gjaldt på godser i Angel og i Svans og de kongelige alsiske ladegårde, hvor der overalt var katastrofale tab. På Gelting døde f.eks. næsten alle køer 1751, og også på Dyttebøl, Udmark og Østergårde var der på den tid igen store tab. Men mens dødelighedsprocenten 1745/46 havde været næsten $100 \%$, overlevede nu et betydeligt antal. De må være blevet immune. På Gelting overlevede 1751 således $20 \mathrm{køer}$ og en tyr ${ }^{95}$.

Kvægpesten fortsatte i begyndelsen af 1750'erne og satte igen ind med vekslende styrke fra 1762. Den synes navnlig da at have været hård ved besætningerne i Svans og på Nordals.

Kvægsygen medførte, at hollænderierne gennemgående ikke nåede op på samme størrelse som før 1745/46. På Mjelsgård, hvor den ordinære besætning var $80 \mathrm{køer}$, var den 1754 på $60^{96}$ På Søgård skete en reduktion fra 157 køer til 84 i 1763, men 1764 var den dog igen oppe på 92. På Fiskebæk halveredes besætningen fra 120 køer før 1745 til 60 i 1750'erne. Også på Avnbølgård faldt besætningen fra 60 til $30 \mathrm{k} ø e r$, mens reduceringen på Kiding og Årup var noget mindre - fra henholdsvis 180 til 120 og 100 til $80 \mathrm{køer}^{97}$. På Sønderborg ladegård faldt besætningen fra ca. 170 til 74 .

Andetsteds bestræbte man sig dog for at få besætningerne op på samme niveau som før kvægsygen. På Gammelgård var køernes antal o. 1800 det samme som o.1700, og det samme gjaldt nogle godser i Angel. På Runtoft steg antallet fra 240 før 1745 til 300 køer i 1755 for dog i 1760'erne at stabilisere sig til 240. På den under Runtoft hørende avlsgård Drølt var der før og efter 1745130 køer, og også i Svans synes man at have bestræbt sig for hurtigst muligt at få hollænderierne op på fuld styrke. På Hemmelmark, hvor besætningen 1745 talte 210 køer, var der 1752198 køer, og på de to avlsgårde Hohenstein og Mohrberg, hvor pensionæren lige efter kvægpesten kunne overtage 


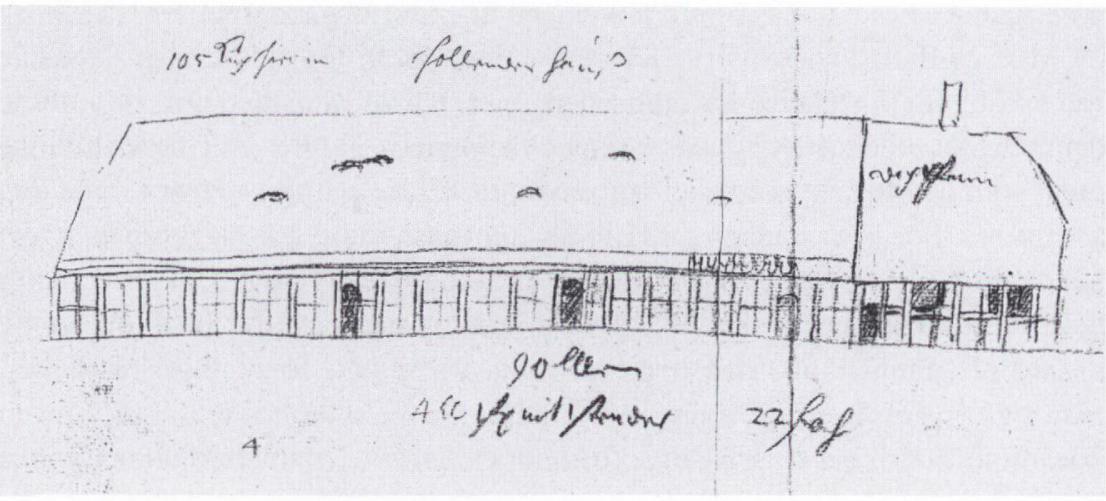

Hollanderi og kostald på Gammelgård i Ketting sogn. Redkridtstegning formentlig fra for 1650, hvoraf fremgär, at bindingsvarksbygningen har haft en langde pd 22 fag pà tilsammen 90 alen $=k n a p 53 \mathrm{~m}$. Over stalden var der stråtag, over hollanderiet med skorstenen tegltag. Sonderborg amtsarkiv nr. 192.

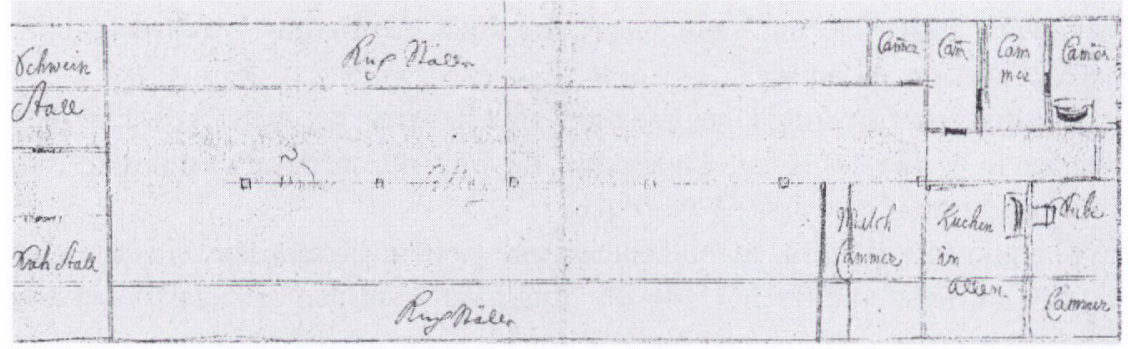

Grundplan af kostald og hollanderi på Gammelgård, Ketting sogn, formentlig fra for 1650. Kostalden kan rumme $105 \mathrm{koer}$, der er anbragt $i$ to lange rakker ind mod ydervaggene. I midten en bred gang. hvor man har kunnet kere ind med vogn ad en port til venstre på tegningen. Selve hollanderiet var på dette tidspunkt endnu kun lille og primitivt. Der var i forbindelse med et kakken, hvor der var abent ildsted, kun et malkekammer. Der var en stue og kammer vel til bolig for hollanderen eller mejersken og endvidere fire kamre til hollanderpigerne, hvoraf det ene kunne opvarmes. Denne del af bygningen siges at vare i dårlig stand. Sonderborg amtsarkiv nr. 192.

en besætning på tilsammen 40 køer, fik han 1749 og 1750 hvert år yderligere 30 køer og 175165 , således at besætningerne 1752 på de to avlsgårde tilsammen talte 165 køer, hvilket tal dog var mindre end før $1745^{98}$. I al almindelighed må siges, at som følge af epizootierne $\mathrm{i}$ sidste halvdel af 1700-tallet var hollænderierne gennemgående mindre på denne tid end de havde været $\mathrm{i}$ århundredets første halvdel. ${ }^{99}$ 


\section{Hollænderibygningerne}

For at kunne forarbejde de til tider ganske betydelige mængder malk til smør og ost måtte man naturligvis have særlige arbejdsrum, som til en begyndelse med de relativt små besætninger vel oftest har været anbragt i en oprindelig til andet formål eksisterende bygning. De kunne, som tilfældet 1726 var på Nygård på Kegnæs, være en del af stuehuset, pensionær- eller forpagterboligen. Men her blev hele det gamle stuehus 1737 dog indrettet til hollænderi ${ }^{100}$. Meget hyppigt fik hollænderiet lokaler i forbindelse med kostalden, således som f.eks. på Gammelgård. Herfra har man bevaret en tegning fra midten af 1600-tallet, hvoraf fremgår, at hollænderiet var indrettet i de østligste fag af en lang og bred kostald, og disse fag var tækket med tegl, mens selve stalden havde stråtag. De gammelgårdske hollænderilokaler var i sammenligning med senere forhold kun få og primitive. Der er således blot et mælkekammer og intet ostekammer, et køkken med åbent ildsted og en stue med bilæggerovn. Endvidere var der et kammer med ildsted og skorsten, men ellers var de øvrige fire kamre uden opvarmning. Her har hollænderpigerne haft deres sengesteder, og det ene af rummene kan vel have været benyttet som sovekammer for hollænderfamilien ${ }^{101}$. Også på Kegnæsgård var hollænderiet 1718 indrettet i 9 fag i den ene ende af den store kostald. Der var her tækket med tegl, og ligesom på Gammelgård var væggene af bindingsværk. På dette tidspunkt var udviklingen videre fremme på Kegnæsgård end på Gammelgård, idet der nu blandt lokaliteterne også nævnes et ostekammer, og i de egentlige arbejdsrum og køkkenet var gulvene af marksten, men i nogle stuer af teglsten. Også her var der naturligvis i køkkenet en stor skorsten, og der nævnes tre sengesteder i pigernes rum. ${ }^{102}$

På Hjortholm på Kegnæs var der allerede 1710 en særskilt teglhængt hollænderibygning på syv fag, som da skildres som meget slet og ringe, men som ikke desto mindre fik lov til at stå til 1734, da den blev afløst af en ny bygning, opført af bygmester Johan Jørgensen, der 1733 havde nedbrudt Østerholm slot og havde anvendt materialerne derfra til opførelse af et nyt hollænderi og til renovering af de øvrige ladegårdsbygninger der ${ }^{103}$. Bygningen på Hjortholm var ikke mindre end 19 fag lang og $51 / 2$ fag bred, altså en bygning af meget anselig størrelse. Ydermurene bestod af 1 1/2 sten tykke brandmure, mens de indvendige skillevægge var bindingsværk med fyrrestolper. Af den bevarede byggekontrakt fremgår, at lofterne skulle være af eg og taget af tegl. Ydermurene skulle kalkes røde og afstreges med hvidt. Vinduerne skulle males med en brunrød oliefarve, og sprosserne skulle være af bly.

Indretningen var nu også mere fuldkommen end ved de tidligere omtalte hollænderier. Der var foruden et »osteværksted« med gulv af marksten og med en åben skorsten med en indmuret jernstang til at hænge kedelkrogen på, et 


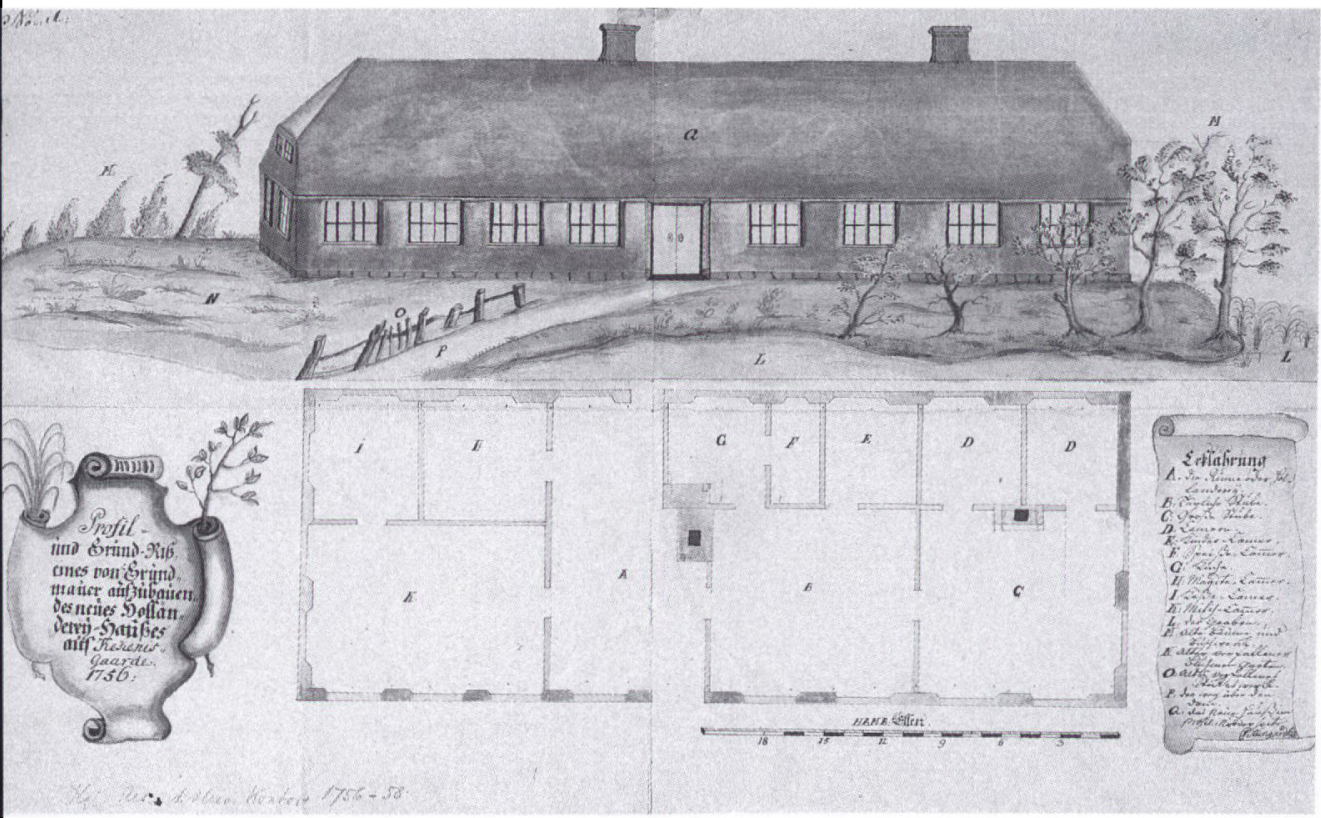

Profil og grundrids til et påtankt hollanderi på Kegnasgård $i$ Lysabild sogn 1756 . Indtil 1758 lå Kegnasgärds hollanderi $i$ samme bygning som kostalden, men 1756 havde Rentekammerets tyske afdeling ladet udarbejde tegning til en ny sarskilt hollanderibygning. Denne tegning blev dog ikke fulgt, men en lignende kombineret forpagter- og hollanderbolig blev opfort 1758. På tegningen ses betegnet med bogstav A det egentlige arbejdsrum, »die Rinne", hvor malken blev behandlet. I=ostekammer og $K=$ malkekammer. Efter 1758 opfortes et sarskilt lille bindingsvarkshus, hvori karnen var anbragt, sandsynligvis trukket ved hjalp af en hestegang. 1756-tegningen er venligst stillet til rådighed af arkivar Margit Mogensen. Den findes $i$ Rigsarkivet, som også har benyttet den som motiv på et postkort. Foto Tage Ludvigsen, Rigsarkivet.

ostekammer med murstensgulv, hvor osten kunne opbevares og lagres. Endvidere var der et stort mælkekammer, et spisekammer, en opholdsstue med bilæggerovn, et par kamre med sengesteder samt et bagekammer. Også andetsteds er bagerum og -ovn bygget sammen med hollænderiet, f.eks. på Nordborg ladegård $1707^{104}$. Der var på Hjortholm i bagerummet en skorsten af brændte sten, og bageovnen var opført af gode teglsten. En del af rummene havde gulve af marksten, andre af teglsten ${ }^{105}$.

Der blev i 1730'erne bygget og repareret meget på de alsiske hollænderibygninger. På Sønderborg ladegård opførtes et særskilt hollænderi 1733 af brandmur og med tegltag, 12 fag langt og fire alen bredt. I ostekammeret her var der foruden ostepressen fire sengesteder til pigerne. Det har næppe for dem været den mest behagelige luft eller duft at sove $i^{106}$.

Mælken skulle opbevares køligt, og derfor var mælkekammeret som regel 
placeret mod nord, på Rønhave i et rum uden vinduer, men med luger og gitterværk, så at frisk luft kunne trænge ind. Man kan undres over, at der kun helt undtagelsesvis nævnes kælder $i$ de alsiske hollænderier. En sådan fandtes dog i det gamle Rønhave hollænderi, der var opført sammen med kostalden 1699, men som 1733 var blevet afløst af en ny bygning. På hollænderiet på Kiding var der en kælder, der strakte sig over seks fag, og som var opført af marksten, vel granit ${ }^{107}$.

\section{Inventar og fremstillingen af mælkeprodukterne}

På vel alle hollænderier blev der både produceret smør og ost, i hvert fald i 1700-årene, og man kan gennem bevarede inventarlister få et ganske godt indtryk af, hvorledes arbejdet må være foregået. På Hjortholm var der $\mathrm{i}$ hollænderiet før 17342 smørtruge, 2 smørkærner, 2 flødebøtter, 1 flødeske, 8 spande med jernhank, 4 små spande, 12 osteforme, 4 gamle osteforme, 1 ostebalje, en stor osteskål, 1 stor mælkebøtte til at sætte tykmælk, 1 jerntrefod samt ikke mindre end 71 mælkebøtter. I 1710 havde man også på Hjortholm en stor kobberkeddel. I det nye hollænderi, opført 1734, fik man i osteværkstedet installeret en solid egetræs ostepresse, som var fremstillet på Sønderborg ladegård, og som hvilede på solide egebjælker. Endvidere nævnes solide jernkroge til at hænge bøtter, gryder og kedler op $i^{108}$. Man får indtryk af, at man her 1734 har indrettet et moderne hollænderi.

Fra Søgård er der bevaret en meget udførlig inventarliste fra 1764. Besætningen var på dette tidspunkt på grund af kvægpest reduceret til 92 mod normalt op mod 160, og det anførte inventar kan derfor være noget overdimensioneret i forhold til besætningens størrelse. Der var her 120 mælkebøtter, 12 mælkespande med jernhank, 4 andre mælkespande, 3 flødekander, 1 lille flødetønde eller -balje, en stor smørkærne med vinde og 18 smørforme. Til ostefremstillingen var der en stor ostebalje på fod. Der var et langt fyrretræsbord, hvorpå osten blev saltet og en bænk, hvorpå den blev presset. Endvidere var der 6 osteforme og to uligestore vallebaljer af eg. Af almindeligt grej, der både kunne anvendes ved smør- og ostefremstillingen, nævnes 4 hårsier, en 1/4 tønde stor kobberkeddel med jernhåndtag og 2 messingkedler, en trebenet jerngryde, en lille strippe samt nogle hanke og forskellige andre mindre genstande ${ }^{109}$.

De mange bøtter skulle kunne rumme 4 - 5 kander, d.v.s. 8 - 10 liter mælk, og de måtte, for at fløden kunne skummes optimalt, højst være $15 \mathrm{~cm}$ høje. De blev fremstillet af bøge- eller egestaver, der blev holdt sammen af vidjeeller hasselbånd. 
I almindelighed overtog hollænderen et standardinventar, hvis vedligeholdelse han var ansvarlig for. Derudover måtte han selv anskaffe forskellige småtterier, som ikke er specielt næunt. Der blev lagt vægt på renholdelse. I inventarerne fra Hjortholm og Søgård nævnes således de store kedler, hvori der varmedes vand, og Dantzmann giver anvisning på, hvorledes man skal holde redskaberne rene. Bøtter og ostekar skal skrubbes i varmt vand med stive skrubber og børster af svinehår for derefter at blive skyllet med rent vand og stillet til tørring i solen eller ved ildstedet. Der krævedes derfor meget brænde, 20 - 30 favne bøgebrænde årligt, til hollænderier på 100 køer, og det har det jo nok været muligt at skaffe i Østslesvig. I nogle egne har man dog sikkert også måttet anvende tørv, selv om røgen herfra kunne give afsmag i produkterne.

Fremgangsmåden ved fremstillingen af smør og ost i 1700-tallets midte er beskrevet af Dantzmann ${ }^{110}$, og den må i det hele og store svare til, hvorledes arbejdet er foregået også i 1600- og 1700-årene i Slesvig. Når mælken af hollænderpigerne var båret ind fra stalden eller hjem fra marken i træspande med jernhanke hængt op i åg, blev den efter at være siet gennem en hårsi hældt over i de omtalte runde, flade mælkebøtter. Her samlede fløden sig - alt efter årstid og omstændigheder - $\mathrm{i}$ løbet af 24-72 timer, hvorefter den blev skummet med en flødeskål med hank eller flødeske og hældt over i flødebøtter eller flødekar, hvori den blev opbevaret, indtil den begyndte at jævnes og blive noget syrlig. Denne udvikling blev fremmet ved, at flødebøtterne ved vintertid blev placeret i nærheden af ildstedet eller på et andet varmt sted. Afskumningen måtte hverken ske for tidligt, fordi fløden da ikke havde sat sig rigtig, eller for sent, når den begyndte at blive direkte sur, da fedtindholdet da ville blive mindre ${ }^{11}$.

Fra flødebøtte eller -kar blev fløden derefter hældt over i kærnen. Denne har vel nok i 1600-tallet og forste halvdel af 1700-tallet været en almindelig stampekærne, som vi kender den fra bondehusholdningerne i sidste århundrede. En sådan kærne bestod af en solid tønde, der var bredest forneden og smallest foroven. I låget var der et hul, hvorigennem gik en lodret stang, på hvis nederste ende var fastgjort en rund eller korsdannet brik. Med håndkraft blev stangen ført op og ned, og fløden blev herved sat i bevægelse, så at der dannedes smør. Det var på de store hollænderier en ret arbejdskrævende og anstrengende fremgangsmåde, og i hvert fald i løbet af 1700-tallet indførtes også i Nordslesvig en mere mekaniseret kærne, hvoraf de ældste via en vinde blev drevet med håndkraft, mens senere de større kærner ved transmissionsanlæg kunne trækkes af en hest. Fløden blev i disse kærner sat $i$ bevægelse ved et såkaldt kærneris sat fast på en akse. Men man kunne også som af Dantzmann beskrevet have en mere sindrig konstrueret indretning, hvorefter en skive, hængt op $\mathrm{i}$ en jernlænke, via vinden hurtigt blev hævet og sænket, hvorved fløden også kunne sættes $\mathrm{i}$ bevægelse ${ }^{12}$. 
De gamle stampekarner kan $i$ dag ikke blot ses pd vore museer, men de opbevares også ofte på gamle gårde som en vardsat antikvitet. Under de to sidste verdenskrige blev adskillige af dem igen taget $i$ brug, sa at man kunne skaffe sig smor uden om rationeringen. Tegnet af arkitekt MAA Jorgen Toft Jessen. Tofilund. Her gengivet efter Peter Kr. Iversen: Landbrug $i$ gamle dage. Trak af Sonderjysk landbrugs historie i 1600-og 1700-ärene, 1983 s. 9.

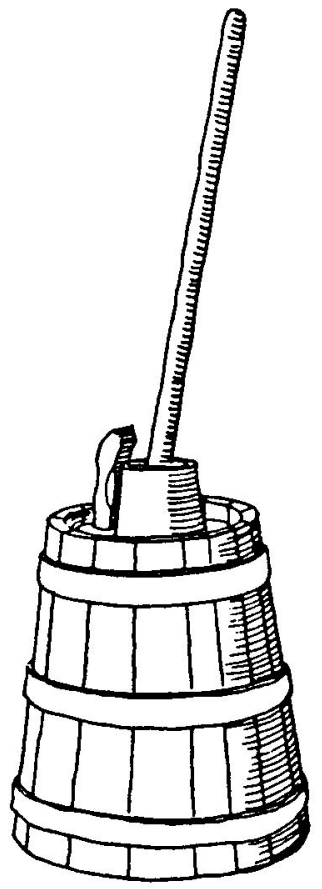

På Søgård nævnes 1764 en stor smørkærne med en vinde, som hollænderipigerne næppe har kunnet sætte $\mathrm{i}$ bevægelse ved håndkraft, men på de alsiske hollænderier har man i første halvdel af 1700-tallet almindeligvis benyttet stampekærnen ${ }^{113}$.

Når smørret var dannet $i$ kærnen, blev det enten bragt over $i$ et smørtrug, hvor det ved sommertid kunne afkøles med vand, og hvor det blev saltet og æltet, eller også blev det bragt over i smørforme, hvor resten af kærnemælken kunne dryppe af. Denne blev særlig god ved anvendelse af stampekærne. Den blev anvendt $i$ hollænderens store husholdning og som svinefoder.

Der blev også produceret ost. De indvandrede hollændere havde fra midten af 1500-årene været læremestre i Ejdersted, og deres efterkommere og lærlinge havde bredt kunsten videre til ladegårde og godser i begge hertugdømmer. Men det er vel først i 1600-årene, at man er begyndt ostefremstillingen i de nordslesvigske hollænderier ${ }^{114}$. Af inventarlisterne kan man få et ret godt indtryk af fremgangsmåden $i$ begyndelsen af 1700-årene. Mælken blev opvarmet i store kobberkedler, der var hængt op i det åbne ildsted. Den opvarmede mælk blev tilsat løbe og hældt over i ostebaljer, hvor ostemassen udskilte sig, og hvorfra vallen kunne fjernes. Ostemassen blev derefter anbragt på et bord, 
hvor den blev saltet og samlet til en homogen masse. Fra bordet kunne den bringes over på en bænk, hvor den yderligere kunne presses for valle, og hvor den blev anbragt i osteforme af varierende størrelse. De største kunne rumme oste på ca. $9 \mathrm{~kg}{ }^{115}$, og disse oste skulle være bedre end de små, da de havde mindre skorpe. I osteformene blev ostemassen sat under yderligere pres for at få de sidste rester af vallen fjernet. På Sønderborg ladegård og Hjortholm havde man i 1700-tallet særlige ostepressere, men det er blevet sagt, at vallen bedst blev presset ud ved anvendelsen af et bræt med en passende vægt på. Efter at ostene havde været $i$ pres et eller to døgn, blev de lagt til tørring og lagring $\mathrm{i}$ dertil særlig indrettede rum eller kamre med god udluftning. For lettere at kunne få ostene solgt, kunne de farves gule med en lage fremstillet af merian og bøgetræsaske. Andre kunne farves grønne ved hjælp af peberrodsblade, hvorved de fik peberrodssmag, andre igen blev farvet med lammelort. Dantzmann føjer til, at hollænderne solgte langt de fleste af disse oste til udlandet, især til Sverige for $5 \mathrm{mk}$. pr. 100 pund plus told og licent ${ }^{16}$. Forhåbentlig var køberne ikke kendt med farvningens mysterier.

Det er uvist, om der på de østslesvigske hollænderier også er fremstillet surmælksoste af skummetmælk tilsat kærnemælk, men meget sandsynligt har det været tilfældet. På Mårkær i Midtangel fremstilledes således sidst i 1500årene noget, der kaldtes »Kese-Botter«, der var en smøreost af tørret surmælk, krydret med øl eller kommen ${ }^{117}$, og på Møgeltønderhus fremstilledes i de første to årtier af 1600-tallet surmælksoste, der kunne afsættes i Tønder ${ }^{118}$. Knapost, der blev fremstillet af kærnemælk, har også været kendt.

Vallen, der blev hældt over i særlige vallebaljer, blev brugt som drikke for mennesker og dyr, nu og da blandet med kærnemælk. Også tykmælk er blevet fremstillet og anvendt som næringsmiddel i 1700-årene.

Til hjælp ved arbejdet havde hollænderen og hans kone et større folkehold, og hans kone eller en mejerske førte tilsyn med, at arbejdet blev ordentligt udført. Noget af det grovere arbejde kunne udføres af en hyrde eller en staldkarl, der kunne bo under primitive forhold $i$ et aflukke i stalden. De større hollænderier havde egen bødker til fremstilling af de mange tønder, bøtter og kar.

Hollænderpigerne skulle normalt malke 18 - 20 køer to gange dagligt. Kun undtagelsesvist har man nøjedes med én daglig malkning, som det var tilfældet på Hemmelmark $1740^{119}$. Det daglige arbejdsskema for en hollænderpige var $\mathrm{i}$ almindelighed således: Man stod om sommeren op $\mathrm{kl}$. 2, og når man havde fået morgenmad, havde fået mælkebøtterne vasket og renset, efter at fløden fra den eller de foregående dage var skummet, kunne pigerne gå ud på malkepladsen på marken, hvor der blev malket under hollænderens tilsyn. Malkningen tog normalt et par timer, og pigerne måtte derefter ved hjælp af 
åg bære mælken hjem i store træspande. Senere hen i 1700-tallet var det ikke ualmindeligt at benytte æsler til hjembringningen af mælken ${ }^{120}$. Selve arbejdet med fremstillingen af smør og ost samt rengøring af de mange redskaber kunne som oftest ikke gøres færdig om formiddagen, og pigerne måtte så efter et par timers middagssøvn fortsætte. Men iøvrigt krævedes det, at pigerne om eftermiddagen arbejdede i den store køkkenhave, der fandtes ved hollænderierne. Der var stort behov for grønsager, først og fremmest kål, til den store husholdning, som med familie kunne tælle omkring 15 personer.

Også efter eftermiddagsmalkningen og aftensmaden kunne hollænderen forlange arbejde af pigerne, naturligvis især om vinteren, hvor mælkemængden var minimal og malkningen derfor ikke tog så lang tid. De kunne så sættes til at spinde, karte og strikke af uld fra hollænderiets får. Det kunne således være lange og strenge arbejdsdage for pigerne, og deres pladser var ikke de mest efterspurgte. Med andre ord var det efter sigende ikke piger med det bedste ry, som arbejdede $i$ hollænderierne, men det synes dog $\mathrm{i}$ hvert fald for de nordslesvigskes vedkommende, at den nedværdigende omtale af dem, man møder i ældre fremstillinger, ikke helt kan holde stik $^{121}$.

Et »umoralsk « levned på den tid gav sig som regel udslag i de såkaldte uægte fødsler, men antallet af disse ses ikke at have været større i de nordslesvigske sogne, hvor der var hollænderier, end i andre. Direkte oplysning om, at en hollænderpige har overtrådt det sjette bud, er kun påtruffet en enkelt gang i Nordborg kirkebog d. 22. søndag efter trinitatis 1722. Bøderegistrene synes heller ikke at underbygge påstanden om de umoralske hollænderpiger ${ }^{122}$.

\section{Staldbygningerne}

Kostaldene kunne som næunt være sammenbygget med selve hollænderiet, men på adskillige af de store avlsgårde lå de separat.

Deres størrelse måtte selvsagt rette sig efter antallet af køer og byggestilen. Derfor træffer man langt mod nord i Sønderjylland store, brede kostalde opført efter sachsisk eller holstensk mønster med høj tagrejsning, hvorved man foruden at få god plads til mange køer også fik plads til store forråd af hø og halm.

Disse stalde var meget brede. På Gammelgård, hvor der i den med hollænderiet sammenbyggede stald kunne stå 105 køer, var denne 23 3/4 alen eller ca. 14 meter bred, og der var i gavlen en $43 / 4$ alen bred port, som det sikkert har været muligt at benytte som køreport, selv om der i den $133 / 4$ alen brede midtergang var placeret en række solide stolper, der var med til at bære taget. Køerne var anbragt $i$ to lange rækker båse, 5 alen lange på begge sider af 


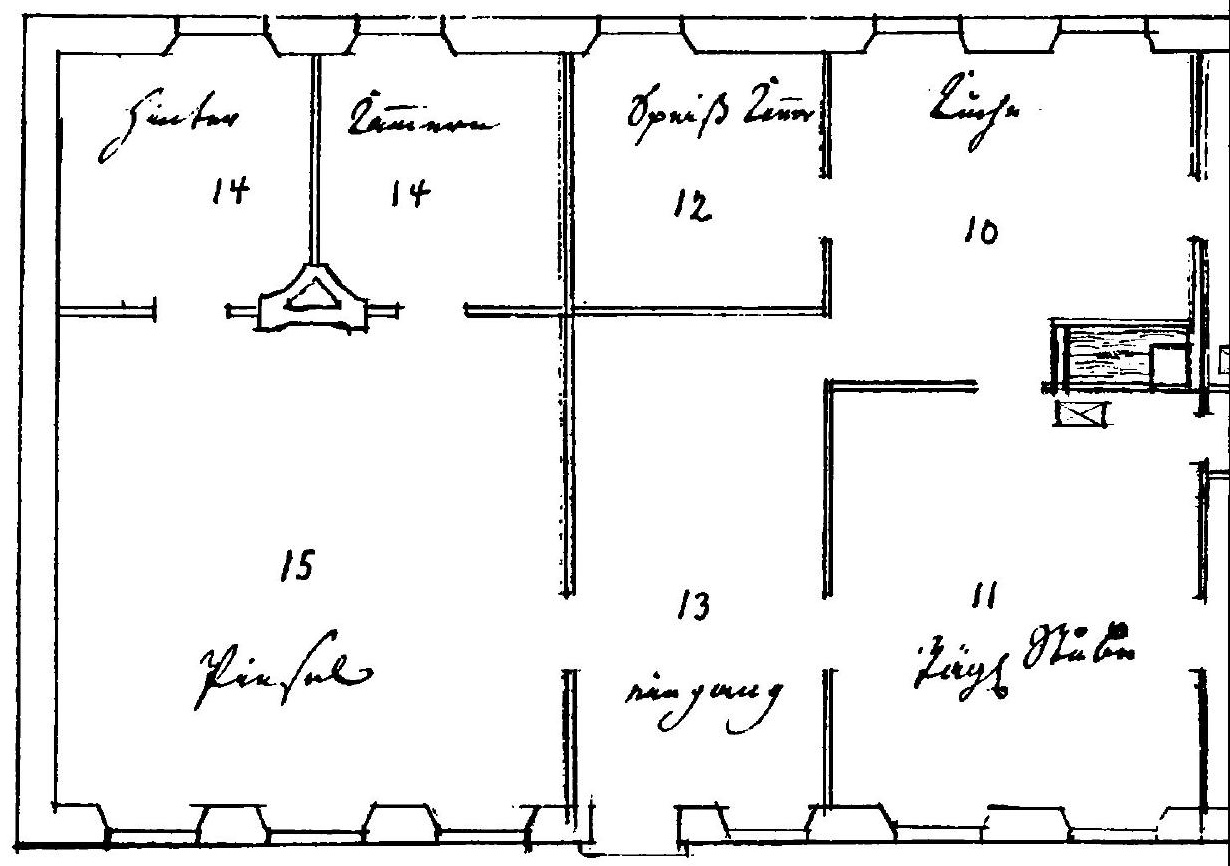

Plan over hollanderibygning pd Gråsten Hovedgård 1800. 1. Milch Kammer=malkekammer. 2. Kees Kammer $=$ ostekammer. 3. Ausgang $=$ udgang. 4. Mädgen Slab Kammer =pigesovevarelse. 5. Wintermilch Kammer = vintermalkekammer. 6. nedgang til Käller $=$ kalder. 7. der Renne $=$ arbejdsrum, hvor der bla. er aflob for vand, og hvor redskaber rengores, smor karnes og ost laves. Her endvidere det abne ildsted og kaldernedgang. 8. Dienst Leute Kammer = folkestue. 9. Kinder- und Slab Kammer= Borne- og sovekammer. 10. Küche =kokken. 11. Tägl. Stube=dagligstue. 12. Speiss Kammer=spisekammer. 13. Eingang =indgang. 14. Hinter Kammer=Bagkamre. 15. Piesel=pisel. Bygningen er ca. 55 alen lang $=k n a p 32 \mathrm{~m}$. Tegningen findes $i$ Augustenborgske og Grästenske godsarkiver, pk. nr. 239.

midtergangen, og så vidt det kan skønnes med hovederne ind mod ydervæggen. Hele bygningen var 22 fag eller 90 alen lang. Staldbygningens totale højde var 20 alen, hvoraf selve stalden udgjorde $73 / 4$ alen og stænget, hø- og halmloftet $121 / 4$ alen. Denne anselige højde, ca. 8 meter, gav $\mathrm{i}$ hvert fald plads til en stor del af de ca. 900 - 1000 les hø, der årligt i begyndelsen af 1700-tallet blev indbjærget på Gammelgård. På en tegning af en anden stor kvægstald på Gammelgård er kreaturerne anbragt med hovederne ind mod en bred fodergang ${ }^{123}$.

De andre alsiske kostalde på hollænderierne mindede om den gammelgårdske. På Hjortspring var kostalden 1707 således 23 fag lang og 9 fag bred ${ }^{124}$. 


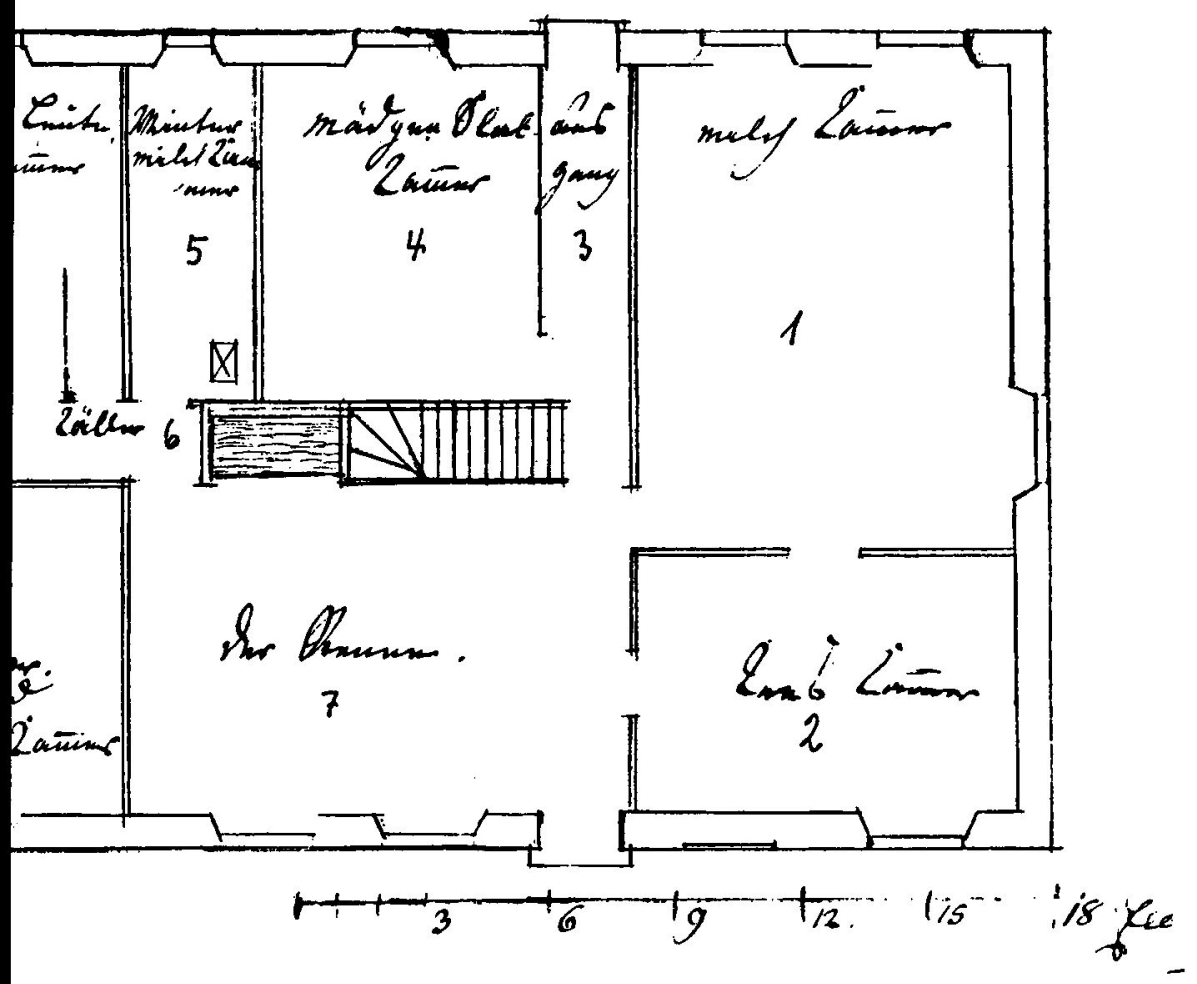

På Østerholm var en kostald til ca. 120 køer opført 1699 og sammenbygget med hollænderiet. Her var selve stalden 18 fag lang og 9 fag bred. Ligesom på Gammelgård var der her en bred gang på langs i midten af bygningen, men her var køerne anbragt $i$ to rækker på hver side af midtergangen, således at der ialt blev fire rækker køer. Foruden en stor port i gavlen var der to døre, så man har haft mulighed for at komme ind til køerne, og disse har kunnet komme ud og ind her ${ }^{125}$.

På Mjelsgård og Nordborg ladegård var hollænderstaldene kun seks fag brede, og her har køerne stået i lange rækker i de henholdsvis 26 og 19 fag lange bygninger ${ }^{126}$.

Staldene i Svans var gennemgående bredere og højere end på Als. På Hemmelmark var stalden 25 fag lang, og grundplanen var 212 fod, d.v.s. 6364 meter, gange 66 fod, d.v.s. ca. 20 meter, hvilket giver et areal på ca. 1270 kvadratmeter. Både på Hemmelmark og Hohenstein har der været to lange gange, så at køerne har været opstaldet i fire lange rækker. På Mohrberg var stalden af en anden konstruktion, vel nærmest noget lignende som på Mjelsgård og Nordborg ladegård. Stalden var dér 22 fag lang og dens grundplan 
$191 \times 36$ fod og højden kun 28 fod. Her må køerne have stået $i$ to rækker, en række på hver sin side af en midtergang ${ }^{127}$. Overalt synes der kun at have været slyd, stænge, over køerne, til opbevaring af hø og halm, til tider vel også af utærsket korn, som kunne tærskes på de brede midtergange.

Staldene var forsynet med bæslinger, spiltræ, d.v.s. skillerum mellem båsene, og der var stolper, hvortil køerne blev bundet. I almindelighed var det overladt til de hoveripligtige bønder og kådnere at flette bindslerne af halm. Var de modvillige med leveringen, kunne andet materiale anvendes. Pensionær Jørgen Petersen på Hjortspring måtte således 1747 binde køerne med snor eller reb, fordi undersåtterne havde nægtet levering ${ }^{128}$. Her og der kunne køerne dog også være bundet med jernlænker.

Iøvrigt synes staldenes udstyr at have været ret så primitivt. Grebninger ses ikke omtalt, og gulvet har formentlig været jord eller stampet ler. Stengulv ses i hvert fald ikke omtalt i de alsiske inventarer. Med krybber har det også været så som så. Kun på Rønhave nævnes 1726 foderkrybber af egetømmer ${ }^{129}$.

Man har været opmærksom på, at der i staldene med den ringe højde og med den tætte opbinding af de mange køer var behov for udluftning. De store porte, luger og lemme måtte derfor ofte åbnes i løbet af dagen ${ }^{130}$.

Med de brede gange i staldbygningerne skulle man ikke synes, at udmugningen kan have været det helt store problem, men alligevel var dette arbejde ikke nogen daglig begivenhed. Det blev normalt ikke udført af hollændere og deres medhjælpere, men af mænd og koner, der kan have udfort arbejdet som hovtjeneste for pensionær eller godsejer. Normalt skete udmugningen to gange ugentlig eller $\mathrm{i}$ hvert fald tre gange i løbet af 14 dage. På de større hollænderier blev møget slæbt ud på møddingen på sluffer forspændt en eller to heste. Tilsynet hermed og opsætningen af møddingen var betroet arbejde, som ladefogeden havde ansvaret for ${ }^{131}$. Da der ingen krybber var $\mathrm{i}$ staldene, måtte køerne daglig løsnes og drives ud til vanding i de store damme, som fandtes ved hvert hollænderi.

\section{Græsning og foder}

Som næunt var der sammenhæng mellem indførelsen af det holstenske kobbelbrug og hollænderierne. Og der skulle store græsningsarealer til de store flokke af malkekvæg. Hedemann-Heespen ${ }^{132}$ mener, at $11 / 4$ tønde land pr. ko på Hemmelmark 1750 er knapt tilmålt. Omregner man det til alsiske forhold, skulle hollænder Boy Hansen 1728/29 på Østerholm have godt 200 tønder græsningsareal udlagt til sine 140 hollænderikøer og 7 egne køer $^{133}$.

Hø var det vigtigste vinterfoder, og der blev derfor på alle gårde indbjær- 


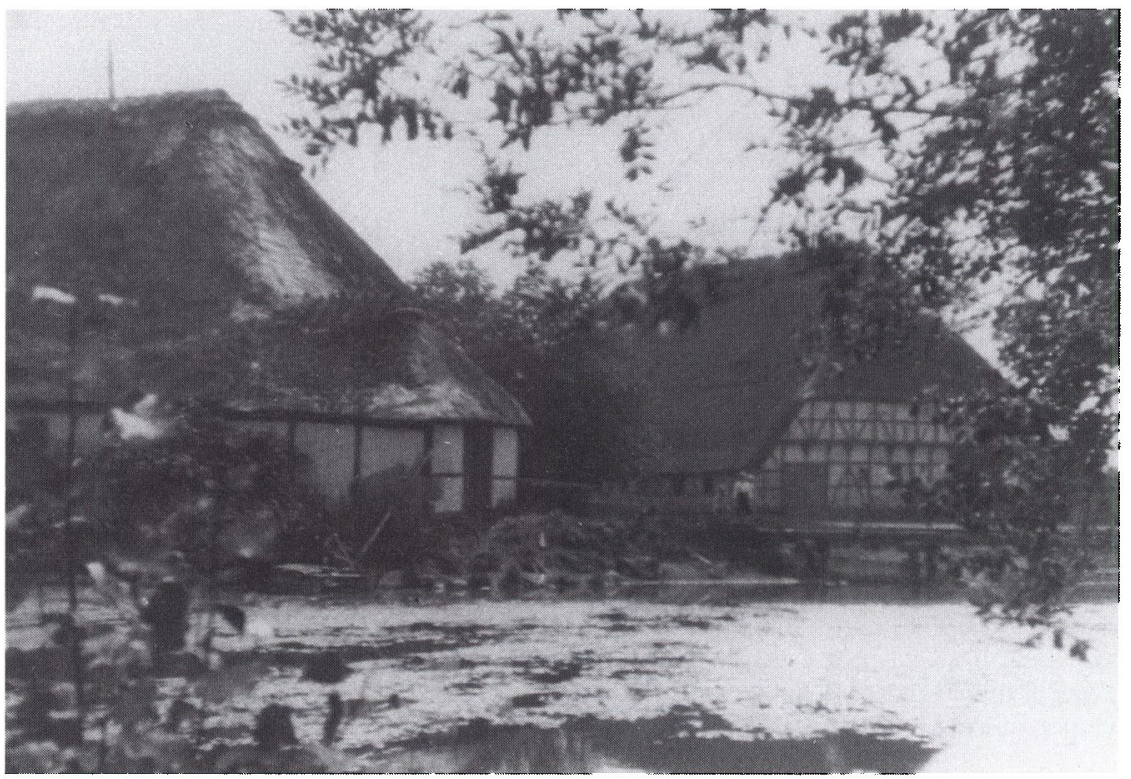

På Rumohrsgård $i$ Notmark sogn kunne man helt frem til vore dage beundre de to store, stråtakte bindingsvarksstalde og -lader af saksisk type med knagtbyggede gavle. Skont de stammede fra 1600tallet - på den ene stod 1630 og 1756 samt hertug Frederik Christians monogram - blev disse i Danmark enestående bygningsvarker nedrevet 1936. Foto i Historiske Samlinger for Sonderjylland.

get mange læs. På Gammelgård kunne der omkring 1670 årligt bjærges 700 - 1000 læs, 40 år senere måtte hovbønderne køre $900-1000$ læs hjem $^{134}$. På Nordborg ladegård kunne der 1730 indbjærges 400 læs $^{135}$, hvoraf hollænderen dog kun fik en del. Det må dog tages i betragtning, at læssene på den tid kun var halvt så store som almindelige hølæs i 1920'erne og 30'erne før motoriseringens tid.

Dantzmann regner med 2 - 4 læs halm pr. ko, hvoraf en del dog er brugt som strøelse, og han nævner, at rughalm er bedst. Derefter følger byg- og boghvedehalm, mens havrehalm kun bør bruges, når der er kærner $i^{136}$. Datidens ringe tærskning med plejl og ofte modvillige hovtærskere efterlod mange kærner i strået, og halmen har derfor sikkert ikke været et helt ringe foder, hvilket også gjaldt avnerne med deres indhold af ukrudtsfrø. Hø har dog været langt det bedste foder, men det kunne ofte være knapt tilmålt. Om fodringen på Hemmelmark ca. 1750 oplyser Hedemann-Heespen, at køerne om vinteren ikke altid kunne få en gift hø om dagen, og at de derfor ofte måtte nøjes med rughalm morgen og aften og to gift havrehalm ind imellem. I stedet for 
havrehalmen kunne der dog også om vinteren gives ca. to tønder havre pr. ko $^{137}$.

\section{Hollændernes økonomi}

Det er vanskeligt på grundlag af det foreliggende kildemateriale at få et blot nogenlunde klart indtryk af hollændernes indtjening og deres økonomiske forhold i det hele taget. Dantzmann ${ }^{138}$ har 1755 foretaget en teoretisk opstilling over en hollænders indtægt ved en besætning på 100 køer. Indtægterne ser således ud:

Salg af smør, ost og mælk Indtagt af fedesvin Indtrgt af 100 spadkalve, hvoraf dog nogle er kastede Vardi af fribolig, brændsel m.v. Indtægt af kvæg- og hesteopdræt
841 rigsdaler 32 skilling

40 rigsdaler

33 rigsdaler 16 skilling

24 rigsdaler

30 rigsdaler

Heroverfor står følgende udgifter:

Forpagtningsafgifter af køerne (à 6 l/2 rdlr.)

Folkehold, løn og kost

Vedligeholdelse af redskaberne

Hollænderens og hustrus løn og kostpenge

Underhold og anskaffelse af to heste, vogne, seletøj m.v.

\begin{tabular}{c}
650 rigsdaler \\
180 rigsdaler \\
20 rigsdaler \\
70 rigsdaler \\
30 rigsdaler \\
\hline 950 rigsdaler
\end{tabular}
180 rigsialer

20 rigsdaler

70 rigsdaler

950 rigsdaler

Netto er hans fortjeneste, når der ses bort fra hans egen og hustruens løn, 19 rigsdaler, der svarer til værdien af 2-3 køer. Tilsammen med værdien af løn og kostpengene bliver årsindtægten ved en besætning på $100 \mathrm{køer} 89$ rigsdaler eller pr. ko knap 43 skilling. Brutto kan indtægten opgøres til godt $91 / 2$ rigsdaler pr. ko. Man kan imidlertid undres over, at der overhovedet ikke er regnet med en udgift til indkøb af salt.

Kan disse budgettal konfronteres med virkeligheden, og kan de overføres til de noget mindre besætninger på de lyksborgske godser eller på de større alsiske og adelige ladegårde og godser på fastlandet? Det kan der på grundlag af det spinkle kildemateriale være vanskeligt nok at tage stilling til, men lidt gætværk kan man vove sig ud i. Først en sammenligning med nogle regnskabstal fra godset Gereby i Svans ${ }^{139}$, hvor der o. 1740 var 350 køer, og hvor det er muligt at sammenstykke en beregning over en hollænders indtjening. 
Forpagtningsafgiften pr. ko var så høj som $71 / 2$ rigsdaler, og den samlede afgift for de $350 \mathrm{køer}$ var altså 2625 rigsdaler. Indtægterne ved salg af mejeriprodukterne var $1742 \mathrm{i}$ alt 3139 rigsdaler 8 skilling, der fordelte sig således: Ostesalg 953 rigsdaler 14 skilling, smørsalg 1885 rigsdaler 13 skilling, kalvehuder 40 rigsdaler 29 skilling, svin 260 rigsdaler. Hollænderens bruttooverskud skulle altså have været ca. 500 rigsdaler. Herfra må trækkes løn og kost til hollænderipigerne. Omkring midten af 1700-tallet må kontantlønnen have beløbet sig til 6 rigsdaler årligt, hvilket var tilfæeldet på Gram, og da der på Gereby må have været omkring 18 piger til de 350 køer, idet hver pige skulle malke 18 - 20 køer, må kontantlønnen her have været ca. 110-120 rigsdaler. Hertil kom i naturalier køb af beklædningsgenstande, gryn og mel til grød, bagning og ølbrygning, idet man vel ikke udelukkende har kunnet nøjes med at drikke kærnemælk og andre affaldsprodukter fra smør- og osteproduktionen. Ialt har Gerebyhollænderen nok måttet regne med i hvert fald 300-500 rigsdaler til medhjælpernes underhold. Endvidere har han haft udgifter til anskaffelse og vedligeholdelse af redskaber. Navnlig har tønderne medført udgifter. På Gereby kan der måske, hvis man går ud fra Dantzmanns tal, regnes med en udgift på ca. 70 rigsdaler hertil. Hollænderens nettofortjeneste kan derefter med forsigtighed anslås til at ligge mellem 100 og 125 rigsdaler eller omkring 17 skilling pr. ko, hvilket er betydeligt mindre end Dantzmann regner med.

På Gereby havde hollænderen indtægter ved salg af kalvehuder. Lignende biindtægter forekommer også på andre hollænderier i form af salg af tælle og huder fra døde køer. På Gram kunne man således 1736 regne med 40 lispund og 14 pund tælle, der blev anvendt til lysestøbning ${ }^{140}$.

Ifølge Waschinski ${ }^{141}$ skulle der $\mathrm{i}$ første halvdel af 1700 -tallet kunne regnes med en pris på 8-9 skilling pr. kg. smør, og med en årsydelse på $45 \mathrm{~kg}$. skulle man i de alsiske hollænderier på denne tid have en bruttoindtægt på mellem $71 / 2-81 / 2$ rigsdaler pr. ko ved smørsalget alene, hvilket tal må sammenholdes med hollænderens forpagtningsafgift på 5 rigsdaler 32 skilling. Herefter har bruttoindtægten pr. ko været et par rigsdaler, og trækker man herfra løn til piger, hyrde og bødker samt kostpenge og andre udgifter, vil hollænderens nettofortjeneste pr. ko nærme sig tallet fra Gereby, d.v.s. en mark.

De alsiske hollændere skulle altså ifølge disse meget skønsmæssige beregninger kunne have haft en minimums årsindtægt på 40 - 50 rigsdaler, hvortil kom forskellige frynsegoder i form af fribolig, køkkenhave, ret til græsning af egne køer, heste, svin og får i større eller mindre antal samt fjerkræhold. Navnlig på de store hollænderier kan hollænderne således siges at have haft en ret solid social position. Enkelte har endda i sidste halvdel af 1700 -tallet haft mulighed for selv at købe godser, som f.eks. Joachim Dietrich Schütt, der 1760 købte 


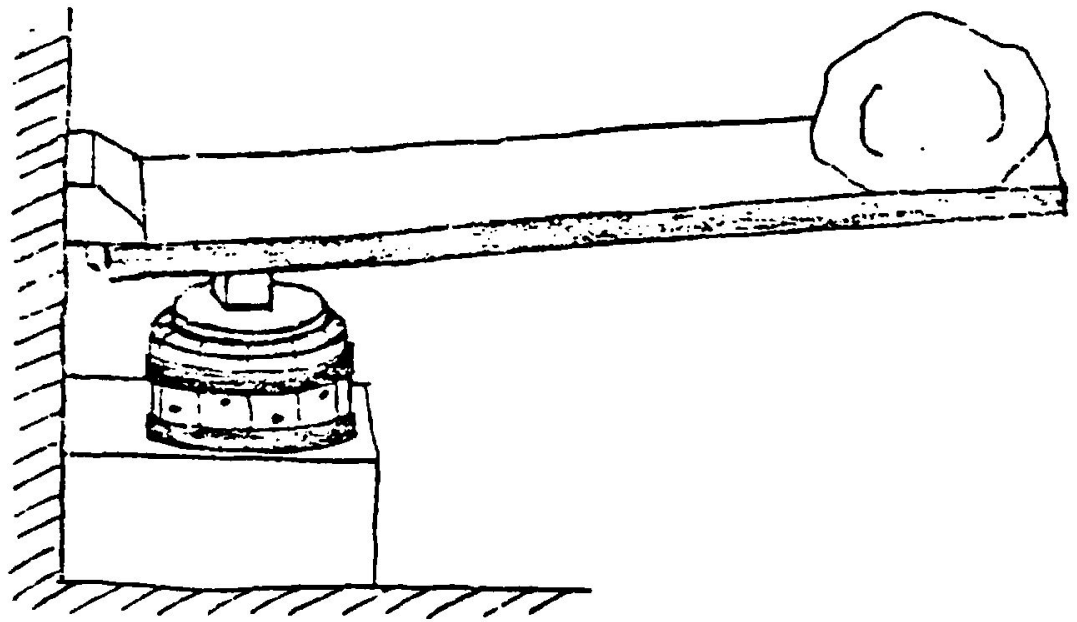

Simpel ostepresse som omtalt side 98 . Anvendes endnu $i$ Vestslesvig ved fremstilling af färeost. Ostemassen anbringes $i$ et stykke larred, for den lagges ned i pressen, som både kan vare rund og rektangular. Med en passende vagt, som regel en stor kampesten, kan vallen derefter $i$ lobet af et dogn presses ud gennem huller $i$ bunden af ostepressen. Gengivet efter tegning i Die Heimat 1985, s. 174.

Tolkskovby i Tolk sogn i Angel, eller de kunne overtage forpagtningen af pensionærgårde. ${ }^{142}$

Kilder og noter

Materialet til artiklen er i det hele og store indsamlet i 1950'erne, og det har desværre ikke senere været mig muligt at foretage supplerende undersøgelser i Rigsarkivet og Landesarchiv SchleswigHolstein i Slesvig.

Hvor intet andet er anført, beror arkivalierne i Landsarkivet i Aabenraa. For Nordborg og Sønderborg amtsarkivers vedkommende henvises til flyttenumrene, som er anført både på kartotekskortene og på de enkelte bind og pakker.

Forkortelser:

La Schl-Holst = Landesarchiv Schleswig-Holstein

Nordb $\quad=$ Nordborg

RA = Rigsarkivet

rgsk = regnskab

Sdbg = Sønderborg

SJy Årb = Sønderjyske Årbøger

Zeitschr = Zeitschrift der Gesellschaft für Schleswig-Holsteinische Geschichte 


\section{NOTER}

1. Festskrift til Troels Fink, 1982, s. 64f.

2. Smst.

3. Jfr. SJy Årb 1949 s. 113 f.

4. W. Buchholtz i Zeitschr 1985, s. 53ff, især 74-82.

5. Johann Baltasar Dantzmann: Bericht von den Holländereyen in den Herzogthümern Schleswig und Holstein, 1755 s. 23.

6. Zeitschr 1985 s. 81 .

7. Georg Hanssen: Agrarhistorische Abhandlungen I, 1880 s. 418.

8. Georg Davids i Die Heimat 1955 s. 161.

9. SJy Årb 1949 s. $101 f$ og Sdbg amtsark nr. 192.

10. Nordb. kirkebog.

11. RA. T.Rtk. Undersøgelseskommissionen i Haderslev amt 1708-15 nr. G 3.

12. Nordb amtsark nr. 32.

13. Smst. nr. 36.

14. Nordb kirkebog. Paul Rabe kan måske være identisk med den hollænder P.R., der døde i Lyksborg 28/7 1719.

15. RA Glücksb. ark. nr. 88.

16. P. Hedemann (Heespen) i Zeitschr bd. 30 side 193 og Joachim Memmert i Familienkundliches Jahrb. Schleswig-Holstein 1989, s. $68 \mathrm{f}$ og 74.

17. Die Heimat 1985 s. $161 \mathrm{f}$.

18. Zeitschr 1985 s. 161 f.

19. Ludwig Andresen: Geschichte Satrupholms, s. 203. Særtryk af Veröffentlichungen des Instituts für Volks- und Landesforschung an der Universität Kiel.

20. Zeitschr bd. 42, s. 33.

21. Munin 1975 s. 48.

22. Nordb amtsark nr. 36.

23. RA. Glücksb nr. 88.

24. Ketting kirkebog.

25. Nordb kirkebog.

26. Nordb amtsark nr. 32.

27. Sdbg amtsark nr. 198.

28. Smst nr. 202

29. Gram godsark nr. 324 .

30. RA Glücksb ark nr. 88.

31. C.E. Andersen: Grams Historie, 1926 s. 122.

32. Oplysningerne hidrører fra Nordb amtsark: Sager vedr. de enkelte ladegårde og korrespondanceprot. R, pag 94 og 782 .

33. Sdbg amtsark nr. 195.

34. Augustenb - gråstenske godsark nr. 242, 244 og 246.

35. Georg Hanssen op. cit. s. 420.

36. Rawitscher i Zeitschr bd. 42 s. 33.

37. Zeitschr bd 30 s. 189.

38. Georg Hanssen op. cit. s. 421.

39. Søgård godsark nr. 222.

40. Dantzmann s. 6.

41. Smst.

42. Sdbg amtsark nr. 195.

43. Zeitschr bd. 30 s. 192.

44. Nordb amtsark nr. 38.

45. Gråsten godsark nr. 242, 244 og 246.

46. Gram godsark. nr. 86. 
47. RA Glücksb ark nr. 88.

48. Jfr. E. Waschinski: Währung, Preisentwicklung und Kaufkraft des Geldes in Schleswig-Holstein 1226-1864, bd. II, s. $182 \mathrm{f}$ og 186.

49. Jfr. flg. afsnit.

50. s. 7.

51. Augustenb og gråstenske godsark nr. 74 og 244, Sdbg amts ark nr. 190, 193 og 196.

52. Nordb. amtsark. nr. 32 og 40.

53. SJy Árb 1949 s. 114.

54. Sdbg amtsark nr. 130.

55. Søgård godsark godsrsk 1747, indlagt seddel.

56. SJy Årb 1943 s. $76 f$.

57. Zeitschr bd. 30, s. 189.

58. Nordb amtsark nr. 38 og 40.

59. Aug. Niemann i Kieler Beiträge II, 1821 s. 211.

60. Nordb amtsark nr. 38 og 40 , Dantzmann s. 21.

61. Georg Hanssen op. cit. s. 422.

62. Festskrift til Troels Fink, 1982 s. 63-74.

63. Min udregning i SJy Årb 1943 s. 77 er forkert.

64. Trøjborg godsark godsrgsk 1603 .

65. Georg Hanssen op. cit. s. 311 jfr. bd. Il s. $469 f$, hvor G.H. anfører, at der pả det holstenske gods Rantzau, nordøst for Plön regnes med $28 \mathrm{~kg} .1635 / 36$.

66. RA Glücksb ark nr. 88 .

67. Niemann op. cit. s. 204, Dantzmann s. 13.

68. Gram godsark nr. 86 og 324.

69. Der er her og flg. efter Fr. Böttger og E. Waschinski: Alte schleswig-holsteinische Masse und Gewichte regnet med 1,91. pr. kande. Ole Rømers pottemảl er 0,9681 og en kande altså 1,936 1.

70. Dantzmann s. 30 og Niemann, Kieler Beiträge II s. $194 f$.

71. Waschinski bd. 1 s. 88 .

72. RA T. rtk. Forestilling $1748 \mathrm{nr} .270$.

73. Smst 1748 nr. 116.

74. Nordb amtsark nr. 32.

75. La Schl-Holst. Abt. 13, Overretten på Gottorp nr. 333.

76. Nordb amtsark nr. 33.

77. Nordb amtsark nr. 34 .

78. Smst nr. 31.

79. Sdbg amtsark nr. 195.

80. Se mit bidrag i Festskrift til Johan Hvidtfeldt, 1978 s. 177-187 og Inger Biehl Hansen i SJy Årb 1990 s. 37-56.

81. La. Schl-Holst. Abt. 13 nr. 335.

82. Sagår godsark godsrgsk 1745.

83. Sdbg amtsark 1733-49. Kopibog over breve til overordnede $11 / 2$ og 29/3 1746.

84. RA T. rtk. Forestilling $1750 \mathrm{nr}$. 178.

85. RA TKIA Reskriptbog 1745 s. 575f, $174528 / 5$.

86. RA T rtk. Forestilling nr. $270,1748$.

87. Smst 1750 nr. 324.

88. La Schl-Holst Abt. 13, nr. 335.

89. RA TKIA Reskriptbog 1745, s. 575f, 1745 28/5.

90. RA TKIA Reskriptbog 1745 s. 818f, 1745 23/7.

91. Zeitschr. bd. 30 s. 189.

92. Sdbg amtsarkiv kopibog over breve til underordn. 1746 8/10, samme til overord. 1747 7/4.

93. Søgård godsark rgsk 1748-49.

94. Nordb amtsark nr. 101747 kopibog A nr. 94. 
95. La Schl-Holst. Abt. 13B, spec.reg. 59 nr. 1751 indbr. 1762-63.

96. Nordb amtsark nr. 38.

97. Augustenb og gråstenske godser nr. 244 og 246.

98. Zeitschr 30 s. 174, 178, 181 og 188.

99. Nordb amtsark nr. 36 og Niemann op. cit. s. 206.

100. Sdbg amtsark nr. 190 og 196.

101. Smst nr. 192.

102. Smst nr. 194.

103. Nordb amtsark nr. 28.

104. Smst nr. 31.

105. Sdbg amtsark nr. 193.

106. Smst nr. 200.

107. Augustenb og gråst. godser nr. 244. Dantzmann s. 26.

108. Sdbg amtsark nr. 193.

109. Søgård godsark nr. 222.

110. Dantzmann s. $25 \mathrm{ff}$.

111. Niemann op. cit. s. 189.

112. Dantzmann s. 28.

113. Søgård godsark. nr. 222.

114. Ang. fremstillingen af surmalksoste på Møgeltønderhus i beg. af 1600-tallet se SJy Årb 1943 s. $78 \mathrm{f}$.

115. Dantzmann, s. 34.

116. Smst s. 35 .

117. Festskrift til Troels Fink, 1982 s. 71.

118. SJy Årb 1943 s. 77.

119. Zeitschr bd. 30 s. 115.

120. SJy Årb 1949 s. 115.

121. Jfr. f.eks. Die Heimat 1928 s. 131 og Niemann i Kieler Blätter II s. 232f.

122. Jfr. f.eks. RA Glücksb ark nr. 88.

123. Sdbg amtsark nr. 192. SJy Årb 1949 s. 109f.

124. Nordb amtsark nr. 40.

125. Smst nr. 32.

126. Nordb amtsark nr. 31 og 38 .

127. Zeitschr br. 30 s. 188.

128. Nordb amtsark nr. 40.

129. Sdbg amtsark nr. 198.

130. Dantzmann s. 39.

131. Dantzmann s. 38.

132. Zeitschr bd. 30 s. $190 \mathrm{f}$.

133. Nordb amtsark nr. 36.

134. Sdbg amtsark nr. 31.

135. Nordb amtsark nr. 31.

136. Dantzmann s. 9, Niemann i Kieler Blätter II s. 204.

137. Zeitschr bd. 30 , s. 190 f.

138. Dantzmann s. 36f.

139. Rawitscher i Zeitschr. bd 42 s. 33.

140. Gram godsark nr. 32, godsrgsk 1736.

141. Waschinski op. cit. II s. 186.

142. Memmert op. cit. II s. 74 og 78. 
BILAG

Hollonderier i Sonderjylland ca. 1600-1790

\begin{tabular}{|c|c|c|c|}
\hline Hollænderi & Sogn & $\begin{array}{l}\text { Første gang } \\
\text { set nævnt }\end{array}$ & Antal malkekøer \\
\hline \multicolumn{4}{|l|}{ Als } \\
\hline Gammelgård & Ketting & for 1650 & $1660^{\circ}$ erne/80, 1705/ca. 185 \\
\hline Rumohrsgård & Notmark & før 1650 & \\
\hline Nordborg & Nordborg & 1681 & $1700 / 100,1730 / 110$ \\
\hline Mjelsgård & Oksbøl & 1692 & $1745 / 80,1754 / 60$ \\
\hline Østerholm & Egen & 1696 & $1700 / 100,1730 / 140$ \\
\hline Hjortspring & Svenstrup & 1696 & $1700 / 100,1730 / 134$ \\
\hline Sønderborg & Senderborg & ca. 1700 & $1700 / 118,1733 / 170,1746 / 74$ \\
\hline Nygård & Kegnas & ca. 1700 & $1720 / 170$ \\
\hline Hjortholm & Kegnas & ca. 1700 & $1720 / 160$ \\
\hline Kegnasgård & Lysabild & ca. 1700 & $/ 80.1746 / 81$ \\
\hline Rønhave & Ulkebøl & ca. 1700 & $1710 / 60-70$ \\
\hline Majbølgård & Hørup & ca. 1700 & $1710 / 60,1716 / 35,1722 / 35,1743 / 8$ \\
\hline \multicolumn{4}{|l|}{ Are } \\
\hline Søbygård & Søby & & $1720 / 120$ \\
\hline Gudsgave & Marstal & & $1720 / 100$ \\
\hline \multicolumn{4}{|l|}{ Sundeved } \\
\hline Lundsgård & Ullerup & 1666 & $1667 / 51,1669-78 / 56,1689-95 / 60$ \\
\hline Philipsborg & Ullerup & 1674 & $1675 / 28,1678-95 / 40$ \\
\hline Avnbølgård & Ullerup & 1704 & $1734 / 60,1749 / 30,1757 / 30$ \\
\hline Krammark & Broager & 1667 & $\begin{array}{l}1667 / 28,1673 / 29,1675 / 47,1678 / 50 \\
1678 / 50,1680-9 / 40,1692 / 46, \\
1695-1701 / 50\end{array}$ \\
\hline Nygård & Broager & 1667 & $\begin{array}{l}1669 / 40,1673 / 37,1675-92 / 50 \\
1695 / 50\end{array}$ \\
\hline \multicolumn{4}{|l|}{ Segård-Gråsten } \\
\hline Søgård & Kliplev & & $1726-45 / 157,1763 / 84,1764 / 92$ \\
\hline Arup & Ensted & & $1717-43 / 100,1746 f / 80,1752-65 / 100$ \\
\hline Kiding & Felsted & & $1728 / 180,1757 / 120$ \\
\hline Gråsten & Gråsten & & $1743 / 160$ \\
\hline Fiskebæk & Adsbøl & & $1743-45 / 120,1746 / 25,1751-57 / 60$ \\
\hline Kelstrup & Holbøl & & $1710-38 / 50,1752 / 30$ \\
\hline \multicolumn{4}{|l|}{ Gram } \\
\hline Gramgård & Gram & 1684 & $1740 / 264,1748 / 72,1760 / 249$ \\
\hline \multicolumn{4}{|l|}{ Angel } \\
\hline Nybøl & Kværn & 1666 & $1667 / 76,1692 / 80,1694 / 100,1695 / 95$ \\
\hline Sophiegård & Kværn & 1667 & $1668 / 31,1692-95 / 55$ \\
\hline Rosgård (Philipshof) & Kværn & 1667 & \\
\hline Runtoft & Eskris & 1614 & $\begin{array}{l}1706 / 220, \quad 1720-40 / 240,1755 / 300, \\
1760 \text { 'erne } / 240\end{array}$ \\
\hline Udmark & Eskris & & $1713 / 85$ \\
\hline Dralt & Testrup & & $1706 / 100,1745 / 130,1765 / 130$ \\
\hline Østergård & Stenbjerg & & 1300 \\
\hline Satrupholm & Satrup & 1661 & $\begin{array}{l}1661-79 / 100,1698 / 110, \quad 1726 / 140, \\
1764 / 145\end{array}$ \\
\hline
\end{tabular}


BILAG, fortsat

\begin{tabular}{|c|c|c|c|}
\hline Hollænderi & Sogn & $\begin{array}{l}\text { Første gang } \\
\text { set nævnt }\end{array}$ & Antal malkekøer \\
\hline Opdrup & Satrup & 1669 & $\begin{array}{l}1669 / 80,1679 / 120,1694 / 90 \\
1726 / 100,1764 / 100\end{array}$ \\
\hline Rehbjerg & Satrup & 1685 & $1694 / 50,1726 / 170,1764 / 120$ \\
\hline Bondsbøl & Havetoft & 1660 'erne & $1694 / 60,1726 / 150,1764 / 140$ \\
\hline Mårkær & Bøl & & $1757 / 200$ \\
\hline Skredstrup & Bøl & & $1757 / 80$ \\
\hline \multicolumn{4}{|l|}{ Svans } \\
\hline Gereby, senere Karlsborg & Svans & 1657 & $1740 / 350$ \\
\hline Grønholt & Svans & 1740'erne & \\
\hline Kriseby & Siseby & 1740 'erne & $\begin{array}{l}\text { ca. } 1744 / 120,1745 / 16 \text {, } \\
\text { ca. } 1748 / \text { ca. } 120\end{array}$ \\
\hline Måslev & Siseby & 1740 'erne & \\
\hline Saxtorf & Risby & & $1750^{\prime}$ erne $/ 400$ \\
\hline Kohøved/Ludwigsburg & Vabs & & 1750 erne $/ 400$ \\
\hline Hohenstein & Borreby & 1717 & $1717 / 150,1744 / 140,1763 / 120$ \\
\hline Hemmelmark & Borreby & 1711 & $\begin{array}{l}1711 / 190,1745 / 210,1748 / 100, \\
1751 / 170,1752 / 198\end{array}$ \\
\hline Moorberg & Borreby & 1720 & $1720 / 120,1728 / 110,1745 / 110$ \\
\hline Løjtmark & Borreby & 1740 'erne & \\
\hline Eskildsmark & Kosel & 1686 & $1686 / 70$ \\
\hline Ziegelhof/Louisenlund & Kosel & 1720 & $1720 / 40,1745 / 81$ \\
\hline \multicolumn{4}{|l|}{ Dänischwohld } \\
\hline Lindau & Gettorf & & $1750 / 300$ \\
\hline Noer & Krusendorf & 1670 & \\
\hline Sehested & Sehested & 1619 & \\
\hline Harzhof & Sehested & & $1768 / 150$ \\
\hline Grünhorst & Sehested & & $1768 / 50$ \\
\hline Vindeby & Borreby & 1696 & \\
\hline \multicolumn{4}{|l|}{ Hütten amt } \\
\hline Hütten ladeg. & Hütten & & $1721-45 / 99,1764 / 130-150$ \\
\hline Palhorn & Erfde & 1605 & \\
\hline
\end{tabular}

Anm.: Tabellen bygger på oplysninger fra de kilder, der er anvendt i artiklen samt Lars N. Henningsen: Provinsmatadorer fra 1700 -årene. Reder-, købmands- og fabrikantfamilien Otte i Ekernförde i økonomi og politik, 1700-1770 (1985) s. 56 og 242.

P.S. Ved en beklagelig forglemmelse er de spredte oplysninger, som Wolfgang Prange har meddelt om hollænderierne i sit store vark: Die Anfänge der grossen Agrarreformen in Schleswig-Holstein bis 1771 , ikke kommet med i ovenstảende bilag. P.K.J. 
